\title{
Organic Production Systems in Northern Highbush Blueberry: II. Impact of Planting Method, Cultivar, Fertilizer, and Mulch on Leaf and Soil Nutrient Concentrations and Relationships with Yield from Planting through Maturity
}

\author{
Bernadine C. Strik and Amanda Vance \\ Department of Horticulture, Oregon State University, 4017 ALS, Corvallis, OR 97331 \\ David R. Bryla \\ U.S. Department of Agriculture, Agricultural Research Service, Horticultural Crops Research Laboratory, 3420 NW \\ Orchard Avenue, Corvallis, OR 97330
}

Dan M. Sullivan

Department of Crop and Soil Science, Oregon State University, 3045 ALS, Corvallis, OR 97331

Additional index words. fertilization, weed mat, compost, raised beds, nutrient analysis, Vaccinium corymbosum

\begin{abstract}
The impact of various production systems on leaf nutrient concentration and soil organic matter, pH, and nutrient status was evaluated from the first growing season (2007) through maturity (2016) in a certified organic planting of northern highbush blueberry (Vaccinium corymbosum L.). Treatments included planting method (on raised beds or flat ground), fertilizer source (granular feather meal or fish solubles) and rate ("low" and "high" rates of 29 and $57 \mathrm{~kg} \cdot \mathrm{ha}^{-1} \mathrm{~N}$, respectively, during establishment, increased incrementally as the planting matured to 73 and $140 \mathrm{~kg} \cdot \mathrm{ha}^{-1} \mathrm{~N}$, respectively), mulch [sawdust, yard-debris compost topped with sawdust (compost + sawdust), or black, woven polyethylene groundcover (weed mat)], and cultivar (Duke or Liberty). Mulches were replenished, as needed, and weeds were controlled throughout the study. The impacts of year, planting method, fertilizer, mulch, and cultivar on leaf and soil nutrient levels over this 10-year study were complex with many interactions among treatments. Soil pH remained within the recommended range for all treatments. Plants fertilized with fish solubles had higher leaf $N$, $P$, and $K$ concentrations than those fertilized with feather meal, particularly at the high $\mathbf{N}$ rate in both cultivars. By contrast, fertilization with feather meal increased leaf Ca. Compost + sawdust added a cumulative (2007-16) total of 2274, 400, 961 , and $2744 \mathrm{~kg} \cdot \mathrm{ha}^{-1}$ of $\mathrm{N}$, $\mathrm{P}$, $\mathrm{K}_{\text {, }}$ and $\mathrm{Ca}$, respectively, over the use of sawdust alone, and increased the concentration of $\mathrm{P}, \mathrm{K}$ (as much as $90 \%$ ), Ca, and $\mathrm{Mg}$ in the soil relative to other mulches. Soil organic matter content averaged $4.1 \%$ under compost + sawdust, $3.3 \%$ under sawdust, and $2.9 \%$ under weed mat, averaged over the last 5 years. Mulching with weed mat or compost + sawdust increased leaf $K$ compared with sawdust in both cultivars, regardless of fertilizer treatment. Leaf $\mathrm{Ca}$, on the other hand, was highest with sawdust and tended to be lowest with weed mat in both cultivars. Soil nutrient levels were not consistently correlated with leaf nutrient concentrations, other than between soil $\mathrm{NO}_{3}-\mathrm{N}$ and leaf $\mathrm{N}(5$ years) and between soil and leaf $\mathrm{K}$ (4 years). On average, raised beds resulted in higher concentrations of $\mathrm{N}$, $\mathrm{P}$, $\mathrm{K}, \mathrm{Fe}$, and $\mathrm{Al}$ and lower concentrations of $\mathrm{Ca}, \mathrm{Mg}$, and $\mathrm{B}$ in the leaves than planting on flat ground. Furthermore, concentrations of $\mathrm{N}$ and $\mathrm{Ca}$ in recent fully-expanded leaves at standard sampling time was higher in young plants than in mature plants in both cultivars, whereas the opposite was found for leaf $P$. In 'Duke', yield was positively correlated with leaf Ca in 8 out of 9 years and negatively correlated with leaf $K$ and $P$ in 5 and 6 years, respectively. Leaf $\mathrm{Ca}$ and $\mathrm{Mg}$ were also negatively correlated with leaf $\mathrm{K}$ in most years for both cultivars, as was leaf $N$. Although leaf $N$ concentration was higher with added compost, regardless of fertilizer source in 'Duke', and when fertilized with feather meal in 'Liberty', this was not correlated with yield. High $N$ rates increased leaf $N$ concentration, but did not result in greater yield. While soil and leaf tissue testing are important to help manage fertilizer programs, the lack of a consistent relationship between soil and plant nutrient status and yield was a reflection of the complicated interactions that occurred among nutrients in these organic production systems. Soil nutrient imbalances and changes in leaf nutrient concentrations associated with extended use of compost + sawdust mulch and fish solubles may lead to growth and yield problems in longer-lived plantings. In addition, the loss of organic matter under weed mat would need to be addressed in long-term plantings for sustainable production.
\end{abstract}

\footnotetext{
Received for publication 2 May 2019. Accepted for publication 16 July 2019.

We value the assistance of Gil Buller and Emily Vollmer, former Faculty Research Assistants at the North Willamette Research and Extension Center, Oregon State University, and all of the members of our industry advisory board. We appreciate the funding support provided by the Oregon Blueberry Commission, Washington Blueberry Commission, Northwest Center for Small Fruits Research, and the USDA National Institute of Food and Agriculture (Formula Grant no. OREI 2008-04443).

B.C.S. is the corresponding author. E-mail: bernadine.strik@oregonstate.edu.
}

The northwestern United States is the largest growing region for blueberries ( $\mathrm{Vac}$ cinium corymbosum $\mathrm{L}$.) in the country and, in 2018 , accounted for $48 \%$ of the total production (North American Blueberry Council, unpublished data). This region also accounts for more than $60 \%$ of the total U.S. organic production of blueberries, which continues to increase due to strong markets and an ideal climate for high yield and quality (DeVetter et al., 2015; Fernandez-Salvador et al., 2017; Strik, 2014, 2016). However, $\approx 15$ years ago, organic production only accounted for $\approx 2 \%$ of the total blueberry area in the region (Strik, 2016). Most growers at that time were growing the plants on flat ground, mulched with sawdust, and they were fertilizing with fish solubles (Strik, 2016). Many were concerned with their weed management and fertilizer options, and they wondered whether alternative mulches such as weed mat were better than sawdust. Therefore, we initiated a longterm trial to address key questions related to certified organic production of blueberry (Strik et al., 2017a). Results from this trial revealed that the most economical weed 
control was achieved with weed mat mulch (Julian et al., 2011, 2012; Strik and Vance, 2017), improved root growth and yield occurred when planting on raised beds (Larco et al., 2013a), higher yield occurred with weed mat than with sawdust mulch, improved yield occurred with lower rates of fertilizer $\mathrm{N}$ than those often used commercially, and reduced yield occurred when fertilizing with a fish soluble source, particularly at a high rate (Strik et al., 2017a). Since then, establishing new plantings on raised beds with weed mat mulch has become commonplace, and growers have reduced the total $\mathrm{N}$ applied, in general, and avoid using only fish solubles to provide N, supplementing with other sources (FernandezSalvador et al., 2017; Strik, 2016).

Weed mat (permeable, woven, polyethylene groundcover) is an inert mulch (Granatstein and Mullinix, 2008) and is allowed for use as a weed barrier by the USDA Organic National Program (USDAAMS-NOP, 2011). Weed mat is cost-effective for controlling weeds in blueberry (Julian et al., 2012; Magee and Spiers, 1995; Sciarappa et al., 2008; Strik and Vance, 2017) and results in similar or higher yields than sawdust or bark mulches (Larco et al., 2013a; Krewer et al., 2009; Strik et al., 2017a, 2017b). However, soil temperature is higher under weed mat (Larco, 2010; Neilsen et al., 2003b; Strik et al., 2017a; Williamson et al., 2006), which may affect soil properties and nutrient availability.

Growers are inclined to use plant or animal-based composts in organic production systems. Compost can release $3 \%$ to $10 \%$ of total $\mathrm{N}$ for several years after the initial application (Gale et al., 2006; Sikora and Szmidt, 2001). Improved growth and nutrient status of young blueberry plants occurred when compost was used as part of a fertilizer or mulching program (Burkhard et al., 2009; Larco et al., 2013a, 2013b). However, many composts have high $\mathrm{pH}$ and high levels of $\mathrm{K}$, as well as many other nutrients (Sullivan et al., 2014). Although a preplant amendment of compost containing lime reduced yield in blueberry (Strik et al., 2017b), composts show promise when used as part of a mulching program (Costello et al., 2019; Strik et al., 2017a), and their impact on soil and plant nutrients in long-term plantings remains a key question among growers.

Highbush blueberry needs to fertilized at a rate of $\approx 25-100 \mathrm{~kg} \cdot \mathrm{ha}^{-1} \mathrm{~N}$ per year for optimum growth and production (Bañados et al., 2012; Chandler and Mason, 1942; Eck, 1988; Griggs and Rollins, 1947; Hanson, 2006; Hart et al., 2006). Sullivan et al. (2019) reported equivalent $\mathrm{N}$ mineralization rates $(58 \%$ to $64 \%$ of total $\mathrm{N}$ converted to mineral $\mathrm{N}$ within $28 \mathrm{~d}$ ) for a variety of fish and feather meal fertilizers commonly used by organic growers. We found that cumulative yield was $3 \%$ higher when fertilizing with lower rates of fertilizer $\mathrm{N}$, and that a high rate of fish solubles reduced yield by $35 \%$ in 'Duke' (Strik et al., 2017a). Fish solubles also reduced root lifespan, particu- larly under weed mat mulch in this trial (Bryla et al., 2017). The impacts of longterm use of these organic fertilizers on soil and plant nutrients has not been reported in blueberry.

The objectives of this research trial were to evaluate the impact of planting method, cultivar, mulch type, and fertilizer source and rate on plant growth, yield, and fruit quality from the first growing season (2007) through maturity (2016) in northern highbush blueberry (Strik et al., 2017a). In addition, our goal was to assess the impact of these production systems on plant and soil nutrient status and to describe any relationships between soil nutrient level and yield, soil and leaf nutrient status, and leaf and fruit nutrient concentrations. These latter objectives are reported here. The impacts of treatments on plant growth, yield, fruit quality, and costs of production are reported elsewhere (Julian et al., 2012; Larco et al., 2013a, 2013b, 2014; Strik, 2016; Strik and Vance, 2017; Strik et al., 2017a).

\section{Materials and Methods}

The 0.4-ha trial was established in Oct. 2006 at Oregon State University's North Willamette Research and Extension Center (NWREC; Aurora, OR; lat. 45 $16^{\prime} 47^{\prime \prime} \mathrm{N}$, long. $122^{\circ} 45^{\prime} 23^{\prime \prime} \mathrm{W}$ ). Weather data for this site are available from an AgriMet weather station (U.S. Dept. of Interior, 2014). The planting was certified organic starting in the first cropping year (2008) by a USDAaccredited agency (Oregon Tilth, Certified Organic, Corvallis, OR). The soil, which is mapped as a Willamette silt loam (a finesilty, mixed, superactive mesic Pachic Ultic Argixeroll), contained $3.7 \%$ organic matter content at planting. A pooled soil sample taken before planting indicated that soil $\mathrm{pH}$ (4.9), organic matter (3.7\%), and all nutrients except for $\mathrm{Ca}$ (lower than recommended; 536 $\mathrm{mg} \cdot \mathrm{kg}^{-1}$ ) were at appropriate levels for blueberry (Hart et al., 2006; Strik et al., 2017b). No fertilizers or amendments were applied to the field before establishing the treatments. Further details regarding the establishment of the planting are provided elsewhere (Larco et al., 2013a, 2013b). Plant spacing was $0.8 \mathrm{~m} \times$ $3.0 \mathrm{~m}$ (4385 plants/ha). A permanent grass cover crop was grown in the row aisles and mowed during the growing season, as required. Planting management, disease and pest management, fruit harvest, and pruning were conducted similarly among plots, as described by Strik et al. (2017a, 2007b).

Plants were irrigated using a single line of polyethylene drip tubing (Netafim, Fresno, CA) with $2 \mathrm{~L} \cdot \mathrm{h}^{-1}$ pressure-compensating, inline emitters every $0.3 \mathrm{~m}$. Irrigation was applied three to seven times per week, as needed, and adjusted to maintain similar levels of soil moisture in each treatment (Strik et al., 2017a).

Treatments. There were 48 treatment combinations arranged in a balanced factorial $(2 \times 4 \times 2 \times 3)$ split-split-plot design with five replicates. The main plots were planting method [raised beds $(\approx 0.3-\mathrm{m}$ high) or flat ground], the subplots were fertilizer rate and source ( 2 rates $\times 2$ sources), and the subsubplots were mulch treatment ("compost + sawdust," sawdust, or weed mat) and cultivar (early-season 'Duke' and midseason 'Liberty'). Sub-subplots were 4.6-m long with six plants in each sub-sub-plot at establishment.

Mulch treatments were: a) a 9-cm-deep layer of douglas fir sawdust [Pseudotsuga menziesii (Mirb.) Franco var. menziesii; $360 \mathrm{~m}^{3} \cdot \mathrm{ha}^{-1}$ ]; b) a 4-cm-deep layer of municipal yard-debris compost $\left(152 \mathrm{~m}^{3} \cdot \mathrm{ha}^{-1}\right) \mathrm{cov}$ ered by 5-cm-deep douglas fir sawdust $\left(200 \mathrm{~m}^{3} \cdot \mathrm{ha}^{-1}\right)$ (compost + sawdust); and c) weed mat [black, woven polyethylene groundcover (water flow rate of $6.8 \mathrm{~L} \cdot \mathrm{m}^{-2}$ per h; $0.11 \mathrm{~kg} \cdot \mathrm{m}^{-2}$; TenCate Protective Fabrics; OBC Northwest Inc., Canby, OR)]. Holes (20-cm diameter) cut in the weed mat for the plants were mulched with 5-cm-deep douglas fir sawdust $\left(1.4 \mathrm{~m}^{3} \cdot \mathrm{ha}^{-1}\right)$. Samples of each batch of compost and sawdust were submitted to Soil Control Laboratory (Watsonville, CA) for analysis of macroand micronutrient concentration and bulk density. Yard-debris compost was supplied by Rexius Inc. (Eugene, OR). It was prepared from a mixture of woody tree and shrub trimmings collected from urban yard maintenance. Composting took place outdoors in windrows, with $\approx 30 \mathrm{~d}$ of active $\left(>50{ }^{\circ} \mathrm{C}\right)$ composting, followed by 90 to $180 \mathrm{~d}$ of curing at lower temperatures. On a dry weight basis, compost contained the following $\left(\mathrm{g} \cdot \mathrm{kg}^{-1}\right)$ : organic matter (499), ash (501), organic C (260), total N (11), total P (2), total $\mathrm{K}(6)$, total $\mathrm{Ca}(9)$, and total $\mathrm{Mg}(3)$. On a dry weight basis, sawdust contained the following $\left(\mathrm{g} \cdot \mathrm{kg}^{-1}\right)$ : organic matter (990), ash (10), organic C (491), total $\mathrm{N}$ (1), total $\mathrm{P}$ $(0.2)$, total $\mathrm{K}(1)$, total $\mathrm{Ca}(2)$, and total $\mathrm{Mg}$ $(<0.5)$. The $\mathrm{C}: \mathrm{N}$ ratio was 24 for compost and 494 for sawdust. Dry bulk density was 368 $\mathrm{g} \cdot \mathrm{kg}^{-1}$ for compost and $121 \mathrm{~g} \cdot \mathrm{kg}^{-1}$ for sawdust. Electrical conductivity (EC) $(1: 5 \mathrm{w} / \mathrm{v})$ was 1.4 and $0.3 \mathrm{dS} \cdot \mathrm{m}^{-1}$ and $\mathrm{pH}(1: 5 \mathrm{w} / \mathrm{v})$ was 7.4 and 4.5 for compost and sawdust, respectively. On a dry weight basis, compost contained $12 \mathrm{mg} \cdot \mathrm{kg}^{-1} \mathrm{NH}_{4}-\mathrm{N}$ and $41 \mathrm{mg} \cdot \mathrm{kg}^{-1}$ $\mathrm{NO}_{3}-\mathrm{N}$, and sawdust contained $15 \mathrm{mg} \cdot \mathrm{kg}^{-1}$ $\mathrm{NH}_{4}-\mathrm{N}$ and $2 \mathrm{mg} \cdot \mathrm{kg}^{-1} \mathrm{NO}_{3}-\mathrm{N}$. The organic mulches were initially applied in 2006, just after planting, and were replenished in Jan. 2011, Jan. 2013, and Feb. 2015; in 2015, additional mulch was only needed on raised beds. Table 1 shows the amount of each nutrient supplied through the application of these organic mulches.

Fertilizer source and rate treatments were granular feather meal $(11 \%$ to $13 \% \mathrm{~N}$, depending on product or batch) or fish solubles (pH-stabilized; $4 \%$ to $5 \% \mathrm{~N}$ ). Both were applied at either a "low" or "high" target rate of 28 and $56 \mathrm{~kg} \cdot \mathrm{ha}^{-1} \mathrm{~N}$, respectively, in $2007-09$ and then increased incrementally as the planting matured to 73 and $140 \mathrm{~kg} \cdot \mathrm{ha}^{-1} \mathrm{~N}$, respectively, by 2013. Samples of each fertilizer were submitted to Brookside Laboratories (New Bremen, OH) for analysis of 
nutrient concentration with rates of nutrients applied from fertilizer calculated and presented in Table 2. In some instances, the actual application rate of $\mathrm{N}$ was different from the target rate because the nutrient analysis did not match the percent of $\mathrm{N}$ as stated on the product label. Feather meal was applied in two equal split-applications in March and May. In weed mat plots, the feather meal was concentrated in the openings in 2007-10, and later, once the zippered weed mat was installed (Strik et al., 2017a), it was broadcast on the entire plot in-row area underneath the weed mat. Fish solubles fertilizer was diluted with 10 parts water $(\mathrm{v} / \mathrm{v})$ and applied by hand as a drench around the base of the plants in 2007-09, sidedressed with a sprayer on each side of the row in 2010, and injected through the drip system (fertigation) in 2011-16. Fertilization with fish solubles was split into seven equal applications every 2 weeks from mid April to early July.

Leaf tissue analyses indicated that the concentration of B was low $(<30 \mathrm{ppm})$ in 2009 and 2012-15 (Hart et al., 2006). Therefore, mineral borate was applied to the soil in
Autumn 2010, Spring 2013, and Spring 2014, and boric acid was applied to the foliage in Spring 2010, 2015, and 2016 at rates of $0.7-2.2 \mathrm{~kg} \cdot \mathrm{ha}^{-1} \mathrm{~B}$ per year (Table 2). The concentration of $\mathrm{Ca}$ and $\mathrm{Mg}$ were also low in the leaves in 2012. Therefore, gypsum and epsom salt were applied at rates of 245 $\mathrm{kg} \cdot \mathrm{ha}^{-1} \mathrm{Ca}$ and $56 \mathrm{~kg} \cdot \mathrm{ha}^{-1} \mathrm{Mg}$, respectively, before the 2013 growing season (Table 2).

The cultivars were chosen because of their popularity at the time and their different fruiting seasons. Fertility management was also expected to be more difficult in 'Duke' (more sensitive to $\mathrm{N}$ rate and soil $\mathrm{pH}$ ) than in 'Liberty', based on our experience in conventional systems.

Data collection. Plant tissue (most recent fully expanded leaves in late July to early August from three replicates) samples were collected each year. Leaves were not washed before submission, as recommended by Hart et al. (2006). Ripe fruit were sub-sampled from the second harvest of both cultivars in 2015 and 2016; the only plants that were sampled in this case were those grown on raised beds mulched with sawdust or weed mat and fertilized with feather meal or fish solubles [represented the largest treatment differences for yield (Strik et al., 2017a)]. Tissue samples were analyzed for macro- and micronutrients (plus carbon and moisture content for fruit) by Brookside Laboratories.

Soil samples were collected in autumn of each year (five replicates per treatment). Duke was the only cultivar sampled (to reduce costs and because fewer differences were expected between cultivars for soil than for leaf tissue testing). Two samples were taken per plot and pooled, one per side of each drip line (east and west side of the row) between two plants. Sampling depth was $0.2 \mathrm{~m}$ using a $2.4-\mathrm{cm}$ diameter chromeplated steel soil probe (Soil Sampler Model Hoffer, JBK Manufacturing, Dayton, $\mathrm{OH}$ ). Mulch was removed from the soil surface before taking the samples and replaced afterward. Soil samples were air dried and sent for analysis to Brookside Laboratories. Extractable soil $\mathrm{K}, \mathrm{Ca}, \mathrm{Mg}, \mathrm{Na}, \mathrm{B}, \mathrm{Cu}, \mathrm{Mn}$, $\mathrm{Zn}$, and Al were determined by ICP after extraction of the nutrients using the Mehlich 3 method (Mehlich, 1984). Soil P was extracted with the Bray-1 method and then determined by ICP. Soil $\mathrm{NO}_{3}-\mathrm{N}$ and $\mathrm{NH}_{4}-\mathrm{N}$

Table 1. Total nutrients applied as part of the sawdust and yard-debris compost topped with sawdust mulching treatments in a certified organic production systems trial of northern highbush blueberry at Oregon State University's North Willamette Research and Extension Center, 2006-16.

\begin{tabular}{|c|c|c|c|c|c|c|c|c|c|c|}
\hline \multirow[b]{2}{*}{$\mathrm{Yr}$} & \multirow[b]{2}{*}{ Mulch } & \multicolumn{5}{|c|}{ Macronutrients $\left(\mathrm{kg} \cdot \mathrm{ha}^{-1}\right)$} & \multicolumn{4}{|c|}{ Micronutrients $\left(\mathrm{kg} \cdot \mathrm{ha}^{-1}\right)$} \\
\hline & & $\mathrm{N}$ & $\mathrm{P}$ & $\mathrm{K}$ & $\mathrm{Ca}$ & $\mathrm{Mg}$ & $\mathrm{B}$ & $\mathrm{Mn}$ & $\mathrm{Cu}$ & $\mathrm{Zn}$ \\
\hline \multirow[t]{2}{*}{2006} & Sawdust & 51 & 12 & 2 & 92 & 14 & 0.1 & 2.8 & 0.2 & 0.5 \\
\hline & Compost & 616 & 132 & 31 & 952 & 302 & 0.4 & 30.2 & 4.2 & 10.2 \\
\hline \multirow[t]{2}{*}{2011} & Sawdust & 37 & 3 & 40 & 53 & 7 & 0.8 & 4.5 & 0.2 & 0.4 \\
\hline & Compost & 615 & 101 & 364 & 727 & 179 & 1.2 & 35.2 & 2.1 & 8.4 \\
\hline \multirow[t]{2}{*}{2013} & Sawdust & 69 & 5 & 22 & 30 & 6 & 2.2 & 1.4 & 0.1 & 0.3 \\
\hline & Compost & 613 & 97 & 342 & 613 & 143 & 2.0 & 27.1 & 1.9 & 6.6 \\
\hline \multirow[t]{2}{*}{$2015^{z}$} & Sawdust & 104 & 8 & 24 & 42 & 6 & 0.2 & 1.5 & 0.3 & 0.5 \\
\hline & Compost & 430 & 70 & 224 & 482 & 114 & 0.83 & 21.0 & 2.72 & 5.7 \\
\hline
\end{tabular}

${ }^{\mathrm{z}}$ Sawdust and compost mulch were only applied to raised beds in 2015 , because sufficient quantities were still present on flat ground treatments.

Table 2. Total nutrients from organic fertilizers applied at low and high rates in a certified organic production systems trial of northern highbush blueberry at Oregon State University's North Willamette Research and Extension Center, 2007-16. Target treatment rates are based on the amount of N listed on the label of the fertilizer. Actual rates applied are based on fertilizer nutrient content analysis (Brookside Laboratory, New Bremen, OH).

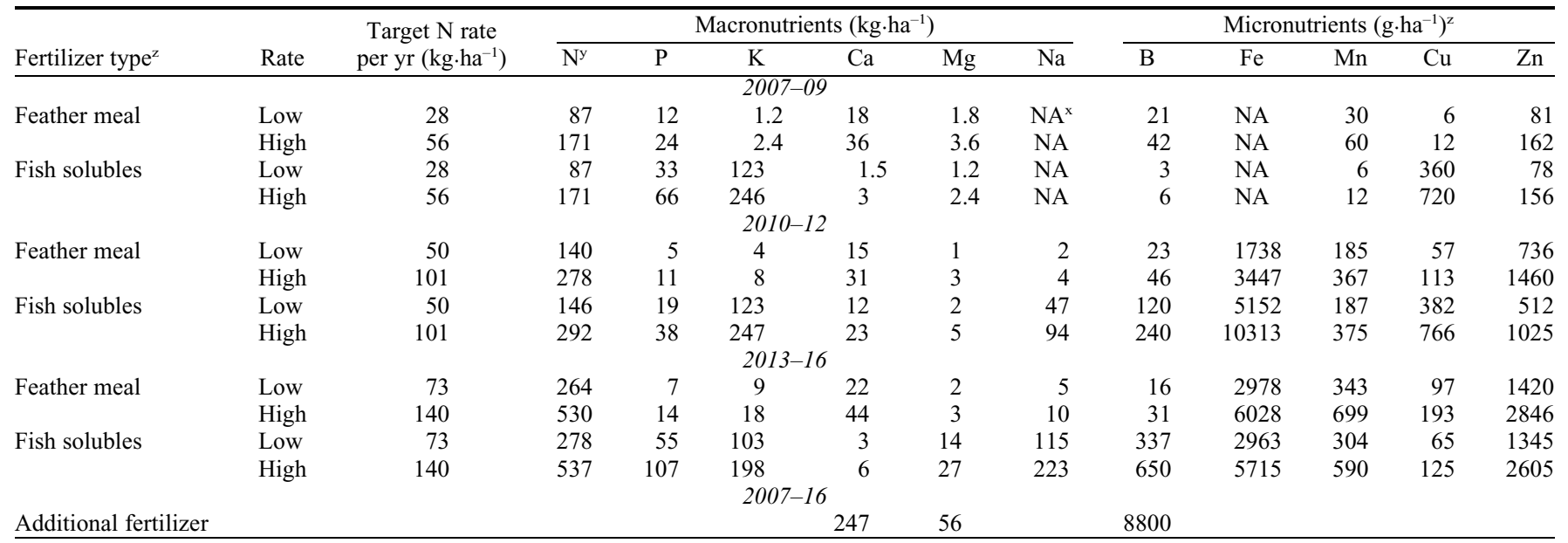

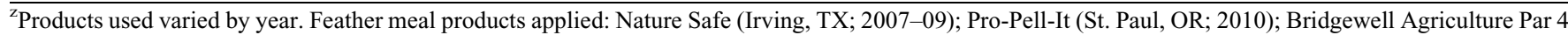
(Clackamas, OR; 2011); California Organic Fertilizers, Phyta Grow Super N (Fresno, CA; 2012-15); Pacific Calcium 11-0-0 (Tonasket, WA; 2016). Fish solubles applied: Fish Agra (Edmonton, Alberta, Canada; 2007-10); TRUE Organic Products TRUE 402 (Spreckels, CA; $2011-12$ ); TRUE Organic Products TRUE 512 (Spreckels, CA; 2013-15); California Organic Fertilizers, Phytamin 420 (Fresno, CA; 2015-16). Additional fertilizers applied: 20 Mule Team Solubor (Chicago, IL; 2010, 2013-16); Pro-Pell-It Gypsum (St. Paul, OR; 2013); Marion Ag Service Magnesium Sulfate (St. Paul, OR; 2013).

${ }^{\mathrm{y}}$ Values shown are cumulative over the indicated time period.

${ }^{\mathrm{x}} \mathrm{NA}=$ not available. 
were determined using automated colorimetric methods after extraction with $1 \mathrm{M}$ $\mathrm{KCl}$ (Dahnke, 1990). Soil organic matter and $\mathrm{pH}$ were measured using Loss-OnIgnition at $360{ }^{\circ} \mathrm{C}$ (Nelson and Sommers, $1996)$ and the 1:1 soil:water method (McLean, 1982), respectively. Levels of $\mathrm{SO}_{4}$-S were not included because these are not generally tested in less arid regions (Horneck et al., 2011).

Statistical analysis. Data were analyzed using PROC MIXED in SAS software package version 9.3 (SAS Institute, Cary, NC). Leaf and soil nutrients were first characterized across years using a split-split-split plot design [year as the main effect $(n=10$ for leaves and $\mathrm{n}=9$ for soil), planting method as the sub-plot $(\mathrm{n}=2)$, fertilizer rate and source as the sub-sub-plot $(\mathrm{n}=4)$, and combinations of cultivar and mulch as sub-sub-subplots $(n=6)]$ and then re-analyzed within years using a complete factorial of the original splitsplit plot design. Contrasts were used to compare the effects of fertilizer source and rate and mulch type on measured variables. Means were separated at the 5\% level using Tukey's honestly significant difference test. Correlation analysis was performed using PROC CORR to determine relationships between leaf nutrients in a particular year and yield of that same year or in the following year within individual plots of 'Duke' and 'Liberty' ( $\mathrm{n}=$ 240). Average fruit nutrient concentration for the season (Fernandez-Salvador, unpublished data) was correlated with leaf nutrient concentration in the same year for plots considered individually for both cultivars in 2015-16 $(\mathrm{n}=80)$. 'Duke' was also analyzed for correlations between soil nutrient concentrations and yield, as well as between soil and leaf and soil and fruit nutrient concentrations $(\mathrm{n}=120)$. Yield data are presented in our previous work (Strik et al., 2017a) with any nutrient relationships presented and described herein.

\section{Results}

There was a significant effect of year and many interactions between production sys- tems and year for soil $\mathrm{pH}$, organic matter, and nutrient levels (Table 3). Because soil testing can be quite variable from year to year (due to sampling method and weather, particularly rain), we are focusing on the more significant effects of production system treatments on various soil nutrient levels or properties and will mention the more notable effects over the study period.

\section{Soil pH and organic matter}

Soil $\mathrm{pH}$. Soil $\mathrm{pH}$ remained between 4.5 and 5.5 in each treatment during the study (data not shown). However, when averaged across the fertilizer sources, soil $\mathrm{pH}$ was lower in plots fertilized with a high $\mathrm{N}$ rate than a lower $\mathrm{N}$ rate in 2008 (5.1 vs. 5.3, respectively) and 2011-16 (5.1 vs. 5.3, respectively). From 2012 to 2016, soil pH was highest under weed mat (5.3), intermediate with compost + sawdust (5.2) and lowest under sawdust (5.0). During this same period, soil $\mathrm{pH}$ was higher on raised beds (5.3) than on flat ground (5.1). There was a significant interaction between mulch type and fertilizer treatment on soil $\mathrm{pH}$ because soil $\mathrm{pH}$ was highest under weed mat when the plants were fertilized with the low rate of fish solubles and highest under compost + sawdust when the plants were fertilized with the high rate of either fertilizer source (data not shown).

Soil organic matter. Soil organic matter responded to mulch treatment. Over the final 5 years of the study (2012-16), soil organic matter content averaged $4.1 \%$ under compost + sawdust, $3.3 \%$ under sawdust, and $2.9 \%$ under weed mat.

\section{Soil nutrients}

Soil $N$. Soil $\mathrm{NO}_{3}-\mathrm{N}$ was significantly higher in raised beds (11 ppm) than flat ground $(7 \mathrm{ppm})$ when the plants were fertilized with the high rate of fish solubles and lowest when the plants were fertilized with the low rate of feather meal (3 ppm). In general, soil $\mathrm{NO}_{3}-\mathrm{N}$ levels were higher on raised beds than on flat ground, regardless of mulch (data not shown). Averaged over planting method, soil $\mathrm{NO}_{3}-\mathrm{N}$ was lower under sawdust and compost + sawdust mulch than under weed mat (Fig. 1). With sawdust and compost + sawdust mulch, soil $\mathrm{NO}_{3}-\mathrm{N}$ was higher in most years when the plants were fertilized with the high rate of fish solubles. In contrast, with weed mat mulch, the high rate of fish increased soil $\mathrm{NO}_{3}-\mathrm{N}$ in the early years of the study, whereas levels were highest for the high rate of feather meal in the later years (Fig. 1C). Soil $\mathrm{NH}_{4}-\mathrm{N}$ was relatively low when the plants were mulched with sawdust or compost + sawdust (2-8 $\mathrm{ppm})$, regardless of fertilizer source or rate, whereas with weed mat mulch, levels were as high as $20-25 \mathrm{ppm}$ when the plants were fertilized with fish.

Soil P. On average, soil $\mathrm{P}$ was higher when the plants were fertilized with the high rate of either fertilizer source (241 ppm) than with the low rate of either source (224 ppm). Soil $\mathrm{P}$ was also higher, on average, under compost + sawdust (240 ppm), intermediate with weed mat (233 ppm), and lowest with sawdust mulch (224 ppm); however, all treatments were well above the recommended sufficiency level for soil P in northern highbush blueberry (Hart et al., 2006).

Soil cations. Soil K was higher when the plants were fertilized with the high rate of either fertilizer source in 2008 and 2011, but thereafter, there was either no effect of treatment or fertilization with fish solubles increased soil $\mathrm{K}$ relative to feather meal from 2012 to 2016 (Fig. 2A). On average, soil K was higher when the plants were mulched with compost + sawdust ( $357 \mathrm{ppm})$ than with sawdust or weed mat (219 ppm), particularly on flat ground (data not shown). Soil $\mathrm{K}$ was excessive (compost + sawdust mulch) or above the recommended soil sufficiency range by the end of the study (Hart et al., 2006).

Soil Ca was higher when the plants were fertilized with feather meal than with any other fertilizer treatment in 2008 and lower when they were fertilized with the high rate of fish solubles in 2011-14 (Fig. 2B). By the end of the study period, soil Ca was highest when the plants were grown with the low rate of either fertilizer source. Soil Ca was highest under compost + sawdust mulch and lowest

Table 3. Results of analysis of variance for the impact of year $(2008-16 ; n=9)$, planting method (raised bed or flat ground; $n=2)$, fertilizer source and rate (feather meal or fish solubles at low or high $\mathrm{N}$ rates; $\mathrm{n}=4$ ), and mulch ( organic matter and nutrients in 'Duke'.

\begin{tabular}{|c|c|c|c|c|c|c|c|c|c|c|c|c|c|c|}
\hline \multirow[b]{2}{*}{ Factor $^{z}$} & \multirow[b]{2}{*}{ Soil pH } & \multirow{2}{*}{$\begin{array}{c}\text { Soil organic } \\
\text { matter }(\%)\end{array}$} & \multicolumn{12}{|c|}{ Soil nutrient concn (ppm) } \\
\hline & & & $\mathrm{NO}_{3}$ & $\mathrm{NH}_{4}$ & $\mathrm{P}$ & $\mathrm{K}$ & $\mathrm{Ca}$ & $\mathrm{Mg}$ & $\mathrm{B}$ & $\mathrm{Fe}$ & $\mathrm{Mn}$ & $\mathrm{Cu}$ & $\mathrm{Zn}$ & $\mathrm{Al}$ \\
\hline Year (yr) & $<0.0001$ & $<0.0001$ & 0.0009 & $<0.0001$ & $<0.0001$ & $<0.0001$ & $<0.0001$ & $<0.0001$ & $<0.0001$ & $<0.0001$ & $<0.0001$ & $<0.0001$ & $<0.0001$ & $<0.0001$ \\
\hline Planting method (PM) & $<0.0001$ & $<0.0001$ & NS & NS & NS & 0.0009 & NS & $<0.0001$ & 0.0206 & 0.0173 & NS & NS & $<0.0001$ & NS \\
\hline $\mathrm{Yr} \times \mathrm{PM}$ & NS & NS & NS & NS & NS & NS & NS & NS & NS & NS & NS & 0.002 & NS & NS \\
\hline Fertilizer (Fert) & $<0.0001$ & 0.0011 & $<0.0001$ & 0.0404 & 0.0001 & $<0.0001$ & $<0.0001$ & $<0.0001$ & NS & 0.0017 & $<0.0001$ & NS & NS & $<0.0001$ \\
\hline Yr $\times$ Fert & $<0.0001$ & NS & $<0.0001$ & $<0.0001$ & NS & $<0.0001$ & 0.0007 & 0.0034 & NS & NS & $<0.0001$ & 0.0002 & NS & 0.0035 \\
\hline $\mathrm{PM} \times$ Fert & 0.0154 & NS & 0.0002 & NS & NS & NS & 0.0001 & 0.002 & NS & 0.0008 & NS & NS & NS & 0.0026 \\
\hline $\mathrm{Yr} \times \mathrm{PM} \times$ Fert & NS & NS & NS & NS & NS & NS & NS & NS & 0.0212 & NS & NS & 0.0212 & NS & 0.0016 \\
\hline Mulch & $<0.0001$ & $<0.0001$ & $<0.0001$ & $<0.0001$ & 0.0051 & $<0.0001$ & $<0.0001$ & $<0.0001$ & $<0.0001$ & $<0.0001$ & 0.0002 & $<0.0001$ & $<0.0001$ & $<0.0001$ \\
\hline Yr $\times$ Mulch & $<0.0001$ & $<0.0001$ & $<0.0001$ & $<0.0001$ & NS & $<0.0001$ & $<0.0001$ & $<0.0001$ & 0.0252 & NS & 0.0021 & NS & $<0.0001$ & 0.0001 \\
\hline $\mathrm{PM} \times$ Mulch & NS & $<0.0001$ & 0.0146 & NS & NS & $<0.0001$ & NS & 0.0149 & NS & NS & 0.01 & NS & $<0.0001$ & $<0.0001$ \\
\hline $\mathrm{Yr} \times \mathrm{PM} \times$ Mulch & 0.0014 & NS & 0.0291 & NS & NS & 0.044 & NS & 0.0057 & NS & NS & NS & NS & NS & NS \\
\hline Fert $\times$ Mulch & $<0.0001$ & NS & 0.0067 & 0.0408 & NS & 0.0057 & 0.0067 & 0.0002 & NS & NS & $<0.0001$ & NS & 0.0166 & 0.0245 \\
\hline Yr $\times$ Fert $\times$ Mulch & NS & NS & $<0.0001$ & $<0.0001$ & NS & NS & NS & NS & NS & NS & NS & NS & NS & NS \\
\hline PM $\times$ Fert $\times$ Mulch & NS & NS & NS & NS & NS & 0.0009 & NS & NS & NS & NS & $<0.0001$ & NS & NS & NS \\
\hline
\end{tabular}

${ }^{\mathrm{z}}$ Results from full analysis of variance. Nonsignificant (NS) or actual $P$ value provided when significant $(P<0.05)$. 
with sawdust for several years during the study period, with soil levels of 1110 and 760 ppm, respectively, at the end of the study.

Soil $\mathrm{Mg}$ was higher when the plants were fertilized with the low rate of fish solubles from 2012 to 2016 and lower with the high rate of feather meal than the other treatments in 2016 (Fig. 2C). Soil Mg was also higher on raised bed plantings (158 ppm) than on flat ground (136 ppm). Weed mat (173 ppm) and compost + sawdust (153 ppm) mulch led to increased soil $\mathrm{Mg}$ compared with sawdust (115 ppm), regardless of fertilizer treatment.

Soil micronutrients. Although there were treatment effects on the level of many soil micronutrients (Table 3), the focus of this study was on soil B because of the measured plant responses and no other micronutrient was considered deficient (Hart et al., 2006; Horneck et al., 2011). Soil $\mathrm{Fe}, \mathrm{Cu}, \mathrm{Mn}, \mathrm{Zn}$, and $\mathrm{Al}$ ranged from 302 to $339 \mathrm{ppm}, 0.7$ to $1.4 \mathrm{ppm}, 14$ to $23 \mathrm{ppm}, 1.1$ to $3.9 \mathrm{ppm}$, and 1233 to $1483 \mathrm{ppm}$, respectively, over the last 5 years of the study (2012-16; data not shown).

Fertilization with the high rate of feather meal increased soil B $(0.53 \mathrm{ppm})$ relative to the other treatments (averaged $0.42 \mathrm{ppm}$ ) in 2016, but only in the raised bed plantings. There was no effect of mulch on soil B during the study period, other than in 2015-16, when levels were higher under compost + sawdust $(0.44-0.53 \mathrm{ppm})$ than under the other mulches (averaged 0.38-0.42 ppm). Soil B was at (compost + sawdust) or just below the recommended soil sufficiency level in each treatment (Hart et al., 2006).

\section{Leaf nutrients}

The impacts of year, planting method, fertilizer, mulch, and cultivar on leaf nutrient concentration over this 10 -year study were complex, with many interactions among the treatments (Table 4). Although there was a main effect of year on the concentration of all leaf nutrients, in all cases, there was an interaction of year with at least one production system treatment (planting method, fertilizer, mulch, or cultivar). Thus, changes in leaf nutrients over the study period (years) are described, with production system interaction effects presented when relevant.

Leaf $N$. There was a year $\times$ fertilizer $\times$ cultivar interaction on the concentration of leaf N (Table 4). In general, leaf N concentration was higher in young plants than in mature plants in both cultivars (Figs. 3A and 4A). Plants fertilized with fish solubles had higher leaf $\mathrm{N}$ than those fertilized with feather meal, and a greater rate of $\mathrm{N}$ application led to higher leaf $\mathrm{N}$ for most years in both cultivars. In 'Liberty', there were relatively large differences in leaf $\mathrm{N}$ among the fertilizer treatments in all years of the study, whereas in 'Duke', differences between fertilizers were relatively small from 2010 to 2013 .

Fertilization with fish solubles, particularly at the high rate, increased leaf $\mathrm{N}$ concentration in all mulch treatments from 2007 to 2009 and in sawdust and compost + sawdust mulch in most of the other years
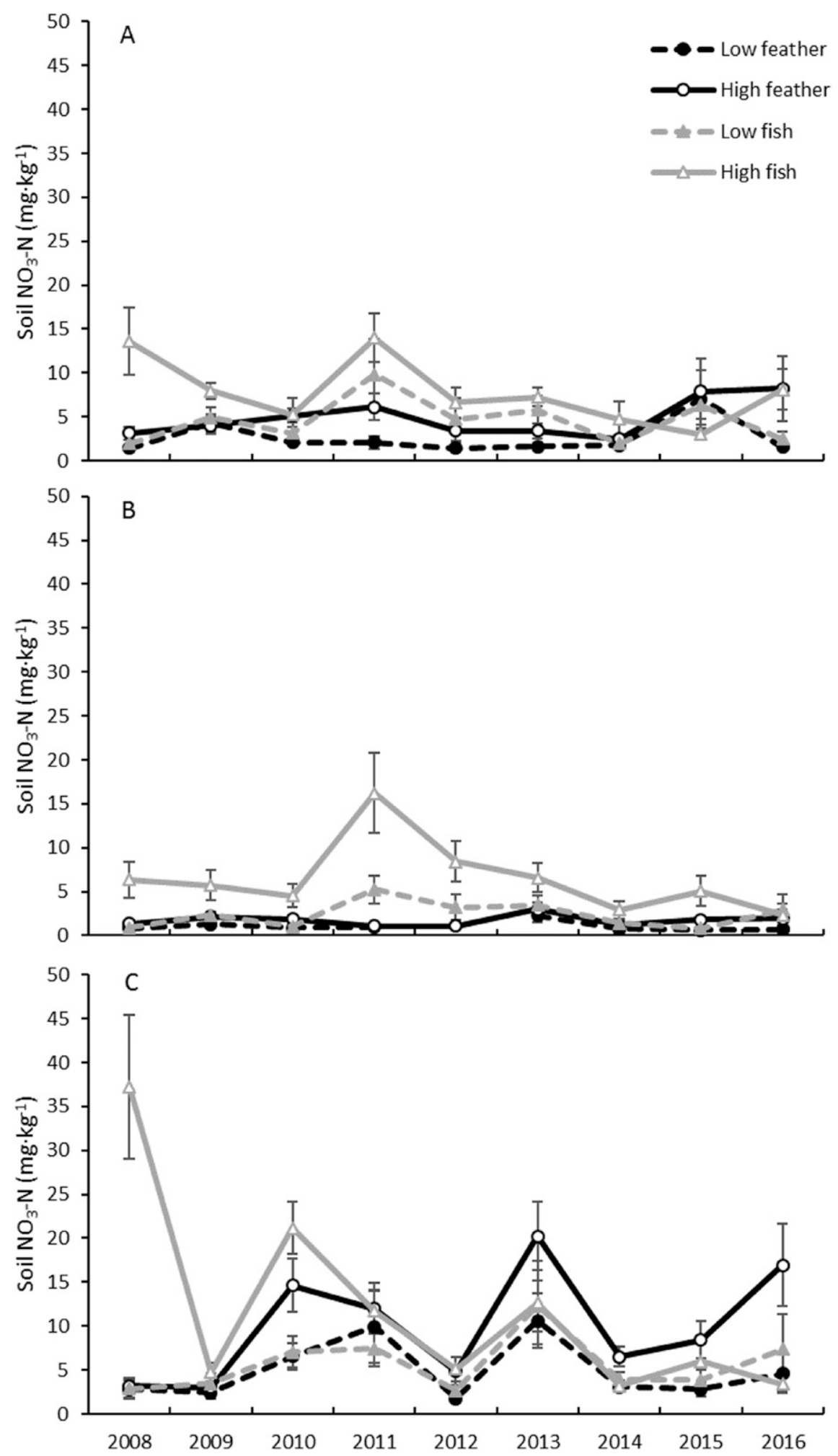

Fig. 1. Effect of fertilizing with low (29-73 kg.ha ${ }^{-1} \mathrm{~N}$ per year) or high $\left(57-140 \mathrm{~kg} \cdot \mathrm{ha}^{-1} \mathrm{~N}\right.$ per year) rates of feather meal or fish solubles on soil nitrate- $\mathrm{N}\left(\mathrm{NO}_{3}-\mathrm{N}\right)$ in 'Duke' northern highbush blueberry plants grown in a certified organic planting at Oregon State University's North Willamette Research and Extension Center from the second through the tenth growing season (2008-16) as affected by mulch: (A) sawdust, (B) compost topped with sawdust (compost + sawdust), and (C) weed mat. Means are averaged over planting method (flat ground and raised beds) treatment. Error bars represent \pm 1 SE.

(Fig. 5A-C). With weed mat mulch, there were fewer effects of fertilizer treatment on leaf $\mathrm{N}$ from 2010 to 2016. On average, leaf $\mathrm{N}$ was highest when the plants were fertilized with the high rate of fish (1.79\%) and lowest when they were fertilized with the low rate of feather meal (1.56\%). Plants mulched with weed mat had a higher leaf $\mathrm{N}$ concentration than those mulched with sawdust, regardless of the source or rate of fertilizer applied in 

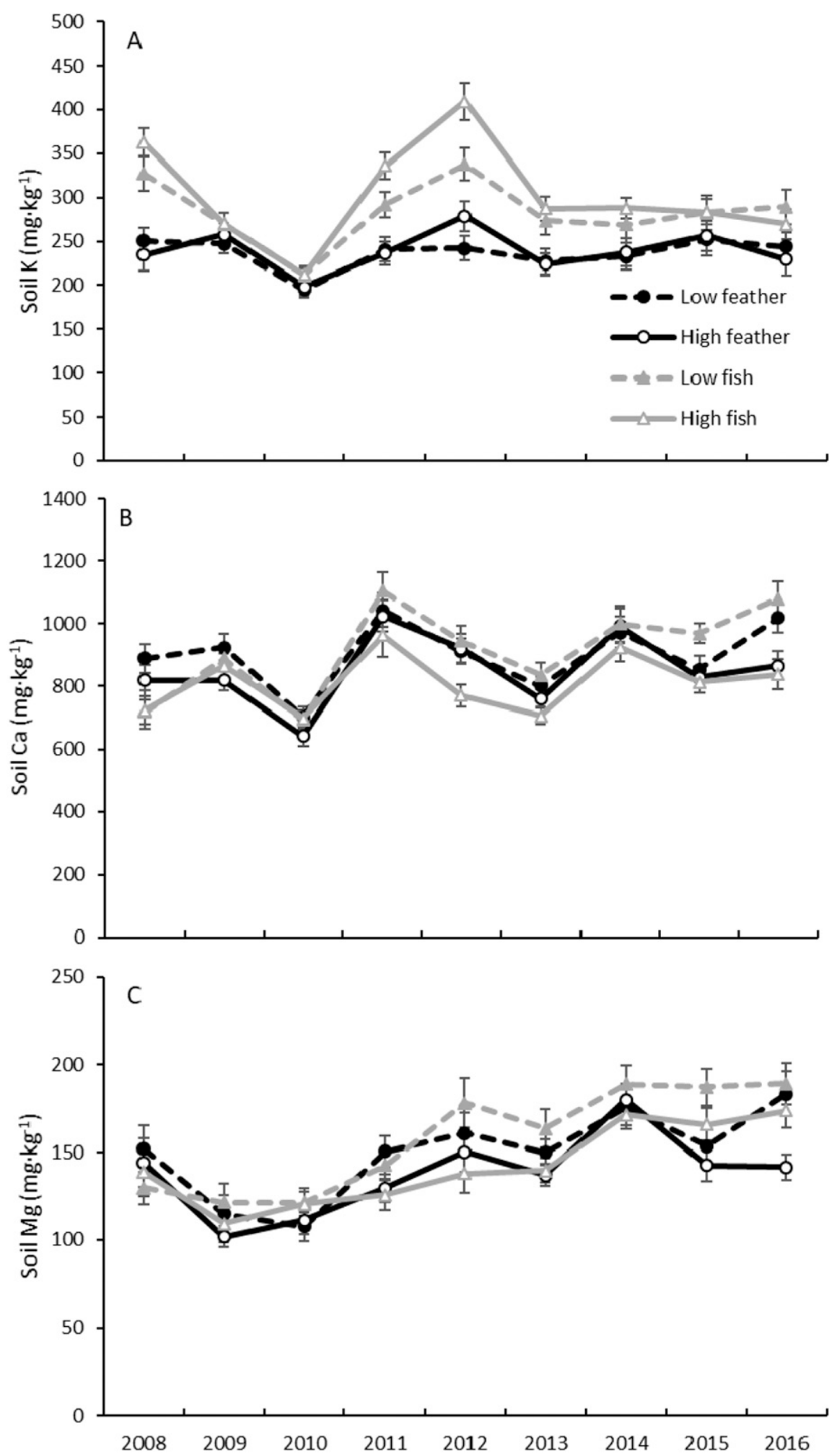

Fig. 2. Effect of fertilizing with low (29-73 $\mathrm{kg} \cdot \mathrm{ha}^{-1} \mathrm{~N}$ per year) or high $\left(57-140 \mathrm{~kg} \cdot \mathrm{ha}^{-1} \mathrm{~N}\right.$ per year) rates of feather meal or fish solubles in 'Duke' northern highbush blueberry plants grown in a certified organic planting at Oregon State University's North Willamette Research and Extension Center from the second through the tenth growing season (2008-16) on soil (A) K, (B) Ca, and (C) Mg. Means are averaged over planting method (raised beds and flat ground) and mulch (sawdust, compost + sawdust, and weed mat) treatments. Error bars represent $\pm 1 \mathrm{SE}$.

'Duke' (Fig. 6A) and for all fertilizers except the high rate of fish solubles in 'Liberty' (Fig. 6B). In addition, plants mulched with compost + sawdust had higher leaf $\mathrm{N}$ than those mulched with sawdust when 'Duke' was fertilized with the low rate of fish solubles, but there were few differences in leaf $\mathrm{N}$ among the mulch treatments in 'Liberty'.

In general, leaf $\mathrm{N}$ concentration was highest when the plants were grown on raised beds with weed mat mulch, but only in the later years of the study (2013-16) (data not shown). On average, over the study period and treatments, 'Duke' had higher leaf $\mathrm{N}$ and $\mathrm{S}$ than 'Liberty' (1.68\% and $1.65 \% \mathrm{~N}$ and $0.12 \%$ vs. $0.11 \% \mathrm{~S}$, respectively).

Leaf $\mathrm{N}$ concentration was below the recommended sufficiency range $(1.76 \%$ to $2.0 \%$; Hart et al., 2006) in most treatments from 2012 to 2016.

Leaf $S$. The impact of year and fertilizer treatment on leaf $\mathrm{S}$ concentration was similar to leaf $\mathrm{N}$ (Figs. 3F and 4F). Plants grown on raised beds had a higher leaf $S$ than those on flat ground, regardless of mulch type. However, the largest differences were found with weed mat $(0.119 \%$ vs. $0.115 \%)$ and sawdust mulch $(0.116 \%$ vs. $0.113 \%)$, compared with relatively little difference with compost + sawdust mulch $(0.115 \%$ vs. $0.114 \%)$, for raised and flat plantings, respectively.

Leaf $P$. There was a year $\times$ fertilizer $\times$ cultivar interaction on leaf $\mathrm{P}$ (Table 4), with concentrations tending to decline from planting establishment to maturity in both cultivars (Figs. 3B and 4B). Fertilization with the high rate of fish increased leaf $\mathrm{P}$ relative to the low rate of feather from 2008 to 2016, with larger differences when the plants were young.

There was also a significant interaction among year, planting method, and mulch on leaf $\mathrm{P}$ concentration (Table 4). Leaf $\mathrm{P}$ was higher, in general, for plants grown with weed mat on raised beds, but only in the later years of the study (2013-16) (data not shown). On average, leaf $\mathrm{P}$ was higher in plants grown on raised beds $(0.12 \%)$ than on flat ground $(0.11 \%)$, especially when they were fertilized with the high rate of feather meal $(0.12 \%$ vs. $0.11 \%$, respectively) or the low rate of fish solubles $(0.12 \%$ vs. $0.11 \%$, respectively).

Leaf $\mathrm{P}$ was higher in plants mulched with weed mat than with sawdust, but differences were greater in 'Duke' than in 'Liberty' (Fig. 6C and D). In 'Duke', leaf $P$ was greater with compost + sawdust than with sawdust when the plants were fertilized with fish solubles; however, there was little effect of these mulches on leaf $\mathrm{P}$ in 'Liberty'. On average, over the study period and treatments, 'Duke' had higher leaf P $(0.14 \%)$ than 'Liberty' $(0.11 \%)$. Leaf P was low $(0.11 \%$ to $0.14 \%$ ) in many treatments in 2009 and 2012-16, relative to published sufficiency levels $(0.11 \%$ to $0.40 \%)$ (Hart et al., 2006).

Leaf cations. There was a year $\times$ fertilizer $\times$ cultivar interaction on the concentration of leaf $\mathrm{K}, \mathrm{Mg}$, and $\mathrm{Ca}$ (Table 4). Plants fertilized with fish solubles, particularly at the high rate in many years, had greater leaf $\mathrm{K}$ in both cultivars (Figs. $3 \mathrm{C}$ and $4 \mathrm{C}$ ). There was less of an impact of rate of feather meal application on leaf $\mathrm{K}$ than with fish. Leaf $\mathrm{Ca}$ concentration increased, in general, from planting establishment to maturity in both cultivars (Figs. 3D and 4D). In 'Duke', leaf Ca was highest when the plants were fertilized with feather meal, particularly at the high rate in most years of the study (Fig. 3D), whereas in 'Liberty', this treatment was only greater 
Table 4. Results of analysis of variance for the impact of year (2007-16; $n=10)$, planting method (raised bed or flat ground; $n=2)$, fertilizer source and rate (feather meal or fish solubles at low or high $\mathrm{N}$ rates; $\mathrm{n}=4)$, mulch (sawdust, yard-debris compost topped with sawdust, weed mat; $\mathrm{n}=3$ ) and cultivar $($ Duke, Liberty; $\mathrm{n}=2$ ) on leaf nutrient concentration (collected in late July-early August of each year).

\begin{tabular}{|c|c|c|c|c|c|c|c|c|c|c|c|c|}
\hline \multirow[b]{2}{*}{ Factor ${ }^{z}$} & \multicolumn{6}{|c|}{ Leaf macronutrient concn $(\%)$} & \multicolumn{6}{|c|}{ Leaf micronutrient concn (ppm) } \\
\hline & $\mathrm{N}$ & $\mathrm{P}$ & $\mathrm{K}$ & $\mathrm{Ca}$ & $\mathrm{Mg}$ & $\mathrm{S}$ & $\mathrm{B}$ & $\mathrm{Fe}$ & $\mathrm{Mn}$ & $\mathrm{Cu}$ & $\mathrm{Zn}$ & $\mathrm{Al}$ \\
\hline$\overline{\text { Year (yr) }}$ & $<0.0001$ & $<0.0001$ & $<0.0001$ & $<0.0001$ & $<0.0001$ & 0.0003 & $<0.0001$ & $<0.0001$ & $<0.0001$ & $<0.0001$ & 0.0338 & $<0.0001$ \\
\hline Planting method (PM) & 0.0048 & $<0.0001$ & $<0.0001$ & $<0.0001$ & 0.0057 & 0.0019 & $<0.0001$ & 0.0259 & $\mathrm{NS}^{\mathrm{y}}$ & NS & NS & 0.0109 \\
\hline $\mathrm{Yr} \times \mathrm{PM}$ & NS & 0.0416 & NS & NS & NS & NS & 0.0094 & NS & NS & NS & NS & NS \\
\hline Fertilizer (Fert) & $<0.0001$ & $<0.0001$ & $<0.0001$ & $<0.0001$ & $<0.0001$ & $<0.0001$ & $<0.0001$ & NS & $<0.0001$ & 0.0007 & NS & NS \\
\hline Yr $\times$ Fert & $<0.0001$ & $<0.0001$ & $<0.0001$ & $<0.0001$ & $<0.0001$ & $<0.0001$ & $<0.0001$ & NS & $<0.0001$ & 0.0247 & NS & NS \\
\hline $\mathrm{PM} \times$ Fert & NS & 0.0186 & NS & $<0.0001$ & 0.0002 & NS & 0.0007 & NS & 0.0119 & NS & NS & NS \\
\hline $\mathrm{Yr} \times \mathrm{PM} \times$ Fert & NS & NS & NS & 0.0387 & NS & NS & NS & NS & NS & NS & NS & NS \\
\hline Mulch & $<0.0001$ & $<0.0001$ & $<0.0001$ & $<0.0001$ & 0.0003 & $<0.0001$ & $<0.0001$ & NS & $<0.0001$ & NS & NS & 0.0002 \\
\hline Yr $\times$ Mulch & $<0.0001$ & $<0.0001$ & $<0.0001$ & 0.0056 & $<0.0001$ & $<0.0001$ & $<0.0001$ & NS & 0.0087 & NS & NS & NS \\
\hline $\mathrm{PM} \times$ Mulch & NS & 0.0488 & 0.0001 & NS & NS & 0.0018 & 0.0317 & NS & NS & NS & NS & NS \\
\hline $\mathrm{Yr} \times \mathrm{PM} \times$ Mulch & 0.0002 & $<0.0001$ & 0.0138 & NS & 0.005 & NS & 0.0021 & NS & $<0.0001$ & NS & NS & NS \\
\hline Fert $\times$ Mulch & 0.0471 & NS & NS & $<0.0001$ & 0.0257 & NS & $<0.0001$ & NS & NS & NS & NS & NS \\
\hline Yr $\times$ Fert $\times$ Mulch & 0.0004 & NS & 0.0001 & 0.0151 & 0.0001 & 0.0385 & NS & 0.0165 & NS & 0.0043 & NS & NS \\
\hline PM $\times$ Fert $\times$ Mulch & NS & NS & NS & 0.0408 & 0.0445 & NS & NS & NS & NS & NS & NS & NS \\
\hline Cultivar (cv.) & $<0.0001$ & $<0.0001$ & $<0.0001$ & $<0.0001$ & $<0.0001$ & $<0.0001$ & $<0.0001$ & 0.0242 & $<0.0001$ & $<0.0001$ & $<0.0001$ & 0.0124 \\
\hline $\mathrm{Yr} \times \mathrm{cv}$ & $<0.0001$ & $<0.0001$ & $<0.0001$ & $<0.0001$ & $<0.0001$ & $<0.0001$ & $<0.0001$ & $<0.0001$ & $<0.0001$ & 0.0024 & $<0.0001$ & 0.0142 \\
\hline $\mathrm{PM} \times \mathrm{cv}$ & NS & 0.0409 & NS & 0.0004 & NS & NS & NS & 0.0291 & 0.0066 & NS & NS & NS \\
\hline $\mathrm{Yr} \times \mathrm{PM} \times \mathrm{cv}$ & NS & $<0.0001$ & NS & NS & 0.0247 & NS & NS & NS & NS & NS & NS & NS \\
\hline Fert $\times \mathrm{cv}$ & NS & $<0.0001$ & 0.0016 & $<0.0001$ & $<0.0001$ & NS & 0.092 & 0.0336 & $<0.0001$ & NS & NS & NS \\
\hline Yr $\times$ Fert $\times$ cv & $<0.0001$ & $<0.0001$ & $<0.0001$ & $<0.0001$ & $<0.0001$ & 0.0340 & 0.0002 & NS & $<0.0001$ & NS & NS & NS \\
\hline $\mathrm{PM} \times$ Fert $\times \mathrm{cv}$ & NS & NS & NS & NS & NS & NS & NS & NS & NS & NS & NS & NS \\
\hline Mulch $\times$ cv & NS & NS & 0.0258 & $<0.0001$ & $<0.0001$ & NS & NS & NS & 0.0005 & NS & NS & NS \\
\hline Yr $\times$ Mulch $\times$ cv & NS & NS & NS & NS & 0.0461 & NS & NS & NS & 0.0003 & NS & NS & NS \\
\hline $\mathrm{PM} \times$ Mulch $\times \mathrm{cv}$ & NS & NS & NS & 0.016 & NS & NS & NS & NS & NS & NS & NS & NS \\
\hline$\underline{\text { Fert } \times \text { Mulch } \times \text { cv }}$ & 0.0382 & 0.0005 & 0.0140 & NS & NS & 0.0061 & NS & NS & 0.0007 & NS & NS & NS \\
\hline
\end{tabular}

${ }^{\mathrm{z}}$ Results from full analysis of variance. $\mathrm{NS}=$ nonsignificant.

than fish in the first growing season and at maturity (Fig. 4D). In both cultivars, leaf $\mathrm{Ca}$ was lowest when the plants were fertilized with the high rate of fish solubles in most years. Leaf Mg increased from 2007 to 2009 but declined in 2010 and 2011 and increased again from 2012 to 2015 (Figs. 3E and 4E). In both cultivars, the leaf $\mathrm{Mg}$ was particularly low in 2012. The impact of fertilizer treatment on leaf $\mathrm{Mg}$ was greatest during establishment of the planting, with the lowest levels in fish-fertilized plants.

Fertilization with fish solubles, particularly at the high rate, increased leaf $\mathrm{K}$ concentration in all mulch treatments from 2007 to 2009 and in most of the other years of the study for the sawdust and compost + sawdust mulches (Fig. 5D-F). There were fewer effects of fertilizer treatment on leaf $\mathrm{K}$ from 2010 to 2016 with weed mat mulch. In general, leaf $\mathrm{K}$ was lowest when fertilizing with the low rate of feather meal.

Although there was little effect of fertilizer rate on leaf $\mathrm{Ca}$ when the plants were mulched with compost + sawdust, fertilizing with the high rate of fish reduced leaf $\mathrm{Ca}$ in plants mulched with sawdust or weed mat (Fig. 5GI). In contrast, fertilizing with the low rate of feather meal increased leaf $\mathrm{Ca}$ from 2011 to 2016 in plants mulched with the sawdust.

Leaf $\mathrm{Mg}$ concentration increased from 2007 to 2009 when the plants were fertilized with fish solubles in each mulch treatment and when they were fertilized with feather meal and mulched with sawdust or compost + sawdust (Fig. 5J-L). Leaf $\mathrm{Mg}$ was lower when the plants were fertilized with fish solubles than with feather meal, but generally only when plants were in their first growing season.
There was a significant interaction of year, planting method, and mulch on leaf $\mathrm{K}$ and $\mathrm{Mg}$ concentration (Table 4). Leaf $\mathrm{K}$ was higher, in general, for plants grown with weed mat on raised beds, but only in the later years of the study (2013-16) (data not shown). Plants grown with sawdust mulch had lower leaf $\mathrm{K}$ than those grown with other mulches in 2007-08 and 2013-16, but only on flat ground (data not shown). Weed mat increased leaf $\mathrm{K}$ compared with sawdust mulch in both cultivars, regardless of fertilizer treatment (Fig. 6E and F). In addition, compost + sawdust mulch increased leaf $\mathrm{K}$ compared with using sawdust alone for all fertilizers in 'Duke' and all but the high rate of fish solubles in 'Liberty'.

There was little effect of planting method on leaf $\mathrm{Mg}$, except for when the plants were young and had higher levels of leaf $\mathrm{Mg}$ on flat ground than on raised beds (data not shown). 'Duke' had higher leaf Mg than 'Liberty' for 7 of the 10 years of the study, averaging $0.17 \%$ and $0.15 \%$, respectively.

Plants grown on raised beds had higher leaf $\mathrm{Ca}$ when fertilized with feather meal than with fish solubles throughout the entire study period, regardless of the rate of fertilizer applied (Fig. 7A). Although leaf $\mathrm{Ca}$ tended to be higher on flat ground for plants fertilized with feather meal than with fish solubles, leaf Ca was similarly high for plants fertilized with the low rate of fish on raised beds during many years of the study (Fig. 7B). Plants grown on raised beds had higher leaf $\mathrm{Ca}$ with sawdust mulch than weed mat when they were fertilized with either rate of feather meal (Fig. 8A), but on flat ground, this only occurred at the low rate of feather meal (Fig. 8B). Leaf Ca was lower with compost + sawdust than with sawdust mulch at the low rate of either fertilizer source on raised beds, but only with the low rate of feather meal on flat ground.

In 'Duke', leaf Ca was higher, regardless of mulch type, when the plants were grown on flat ground $(0.54 \%)$ than on raised beds $(0.50 \%)$, whereas in 'Liberty', plants mulched with compost + sawdust or weed mat had higher leaf $\mathrm{Ca}$ on raised beds $(0.51 \%)$ than on flat ground $(0.49 \%)$. In both cultivars, leaf $\mathrm{Ca}$ was highest with sawdust mulch $(0.53 \%)$ and tended to be lowest with weed mat $(0.50 \%)$.

When mulching with compost + sawdust on raised beds, fertilization with the low rate of fish solubles led to lower leaf $\mathrm{Mg}$ than fertilizing with either rate of feather meal (Fig. 8C). On flat ground, lower leaf $\mathrm{Mg}$ was often found with weed mat mulch, particularly when the plants were grown with a higher rate of fertilizer (Fig. 8D).

Over the study period, leaf K was higher and leaf $\mathrm{Mg}$ and $\mathrm{Ca}$ were lower when plants were grown with weed mat when compared with the sawdust or compost + sawdust mulches (Fig. 5D-L). On average, mulching with sawdust, relative to the compost + sawdust, increased leaf $\mathrm{Mg}$, but had no effect on leaf $\mathrm{K}$ or $\mathrm{Ca}$ (data not shown). Leaf $\mathrm{K}$ was highest, on average, when the plants were fertilized with the high rate of fish $(0.56 \%)$ and lowest when they were fertilized with the low rate of feather meal $(0.49 \%)$. Leaf Ca and $\mathrm{Mg}$, on the other hand, were highest, on average, when the plants were fertilized with the low rate of feather meal $(0.56 \%$ and $0.164 \%$, respectively) and lowest when they were fertilized with the high rate of fish $(0.47 \%$ and $0.157 \%$, respectively). Over the study period and 

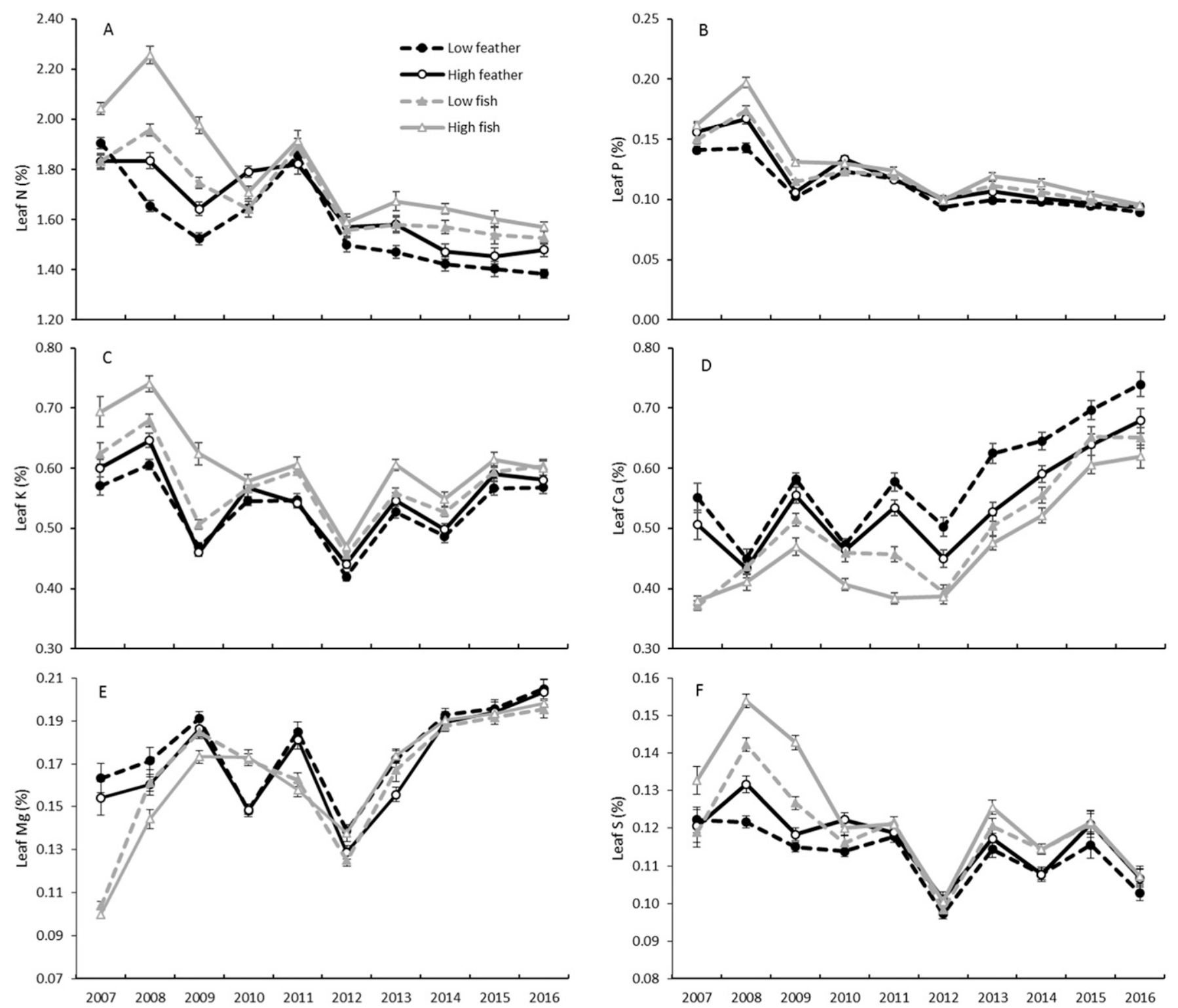

Fig. 3. Effect of fertilizing with low (29-73 kg.ha ${ }^{-1} \mathrm{~N}$ per year) or high (57-140 kg.ha ${ }^{-1} \mathrm{~N}$ per year) rates of feather meal or fish solubles in 'Duke' northern highbush blueberry plants grown in a certified organic planting at Oregon State University's North Willamette Research and Extension Center from the first through the tenth growing season (2007-16) on leaf (A) N, (B) P, (C) K, (D) Ca, (E) Mg, and (F) S concentration. Means are averaged over planting method (raised beds and flat ground) and mulch (sawdust, compost + sawdust, and weed mat) treatments. Error bars represent \pm 1 SE.

treatments, 'Duke' had higher leaf K, Ca, and $\mathrm{Mg}$ concentrations than 'Liberty', and for both cultivars, plants grown on raised beds had higher leaf $\mathrm{K}$ and lower leaf $\mathrm{Ca}$ and $\mathrm{Mg}$ than those grown on flat ground (data not shown).

Leaf $\mathrm{K}$ was below sufficiency $(0.41 \%$ to $0.70 \%$; Hart et al., 2006) in 'Liberty' in 2014 and above recommended levels in plants fertilized with the high rate of fish in 2008. Leaf $\mathrm{Ca}$ was also below recommended levels $(0.41 \%$ to $0.80 \%)$ in 2012 when the plants fertilized with the high rate of fish solubles, whereas leaf $\mathrm{Mg}$ was below sufficiency levels $(0.13 \%$ to $0.25 \%)$ that year in most treatments. All three of these nutrients were sufficient in each treatment in other years.

Leaf micronutrients. There was a significant interaction of year, planting method, and mulch on leaf B concentration (Table 4). Plants grown on flat ground or raised beds had higher leaf B with compost + sawdust mulch when establishing (2007-10), but weed mat led to higher leaf $B$ than the other mulches when the plants were grown on flat ground from 2014 to 2016 (data not shown). Leaf B was also greater when the plants were grown on flat rather than raised beds, particularly when they were fertilized with the low rate of feather meal (35 ppm vs. 28 ppm, respectively). When the plants were mulched with sawdust or compost + sawdust, leaf B was higher with feather meal (averaged 30 ppm) than with fish solubles (26 ppm). In contrast, with weed mat mulch, leaf B was higher with the low rate of feather meal (31 $\mathrm{ppm}$ ) than with the other fertilizer treatments (averaged $28 \mathrm{ppm}$ ). In 'Duke' and 'Liberty', leaf B was higher in plants fertilized with feather meal (43 ppm and $35 \mathrm{ppm}$, respectively) than with fish solubles $(20 \mathrm{ppm}$ for both cultivars) in 2007 ('Duke') and 2007-08 ('Liberty'), but fertilizer effects on leaf B were relatively small thereafter (data not shown). On average, over the study period and treatments, 'Duke' had higher leaf B concentration than 'Liberty' (data not shown). Leaf B was below sufficiency levels (30-80 ppm; Hart et al., 2006) in most years of the study.

There was a significant interaction of year, planting method, and mulch on leaf Mn concentration (Table 4). In general, mulch had more of an effect on leaf $\mathrm{Mn}$ when the plants were grown on flat ground than on raised beds (data not shown). However, 'Liberty' had higher leaf Mn (126 ppm) than 'Duke' (119 ppm), but only when the plants were grown on raised beds; there was 

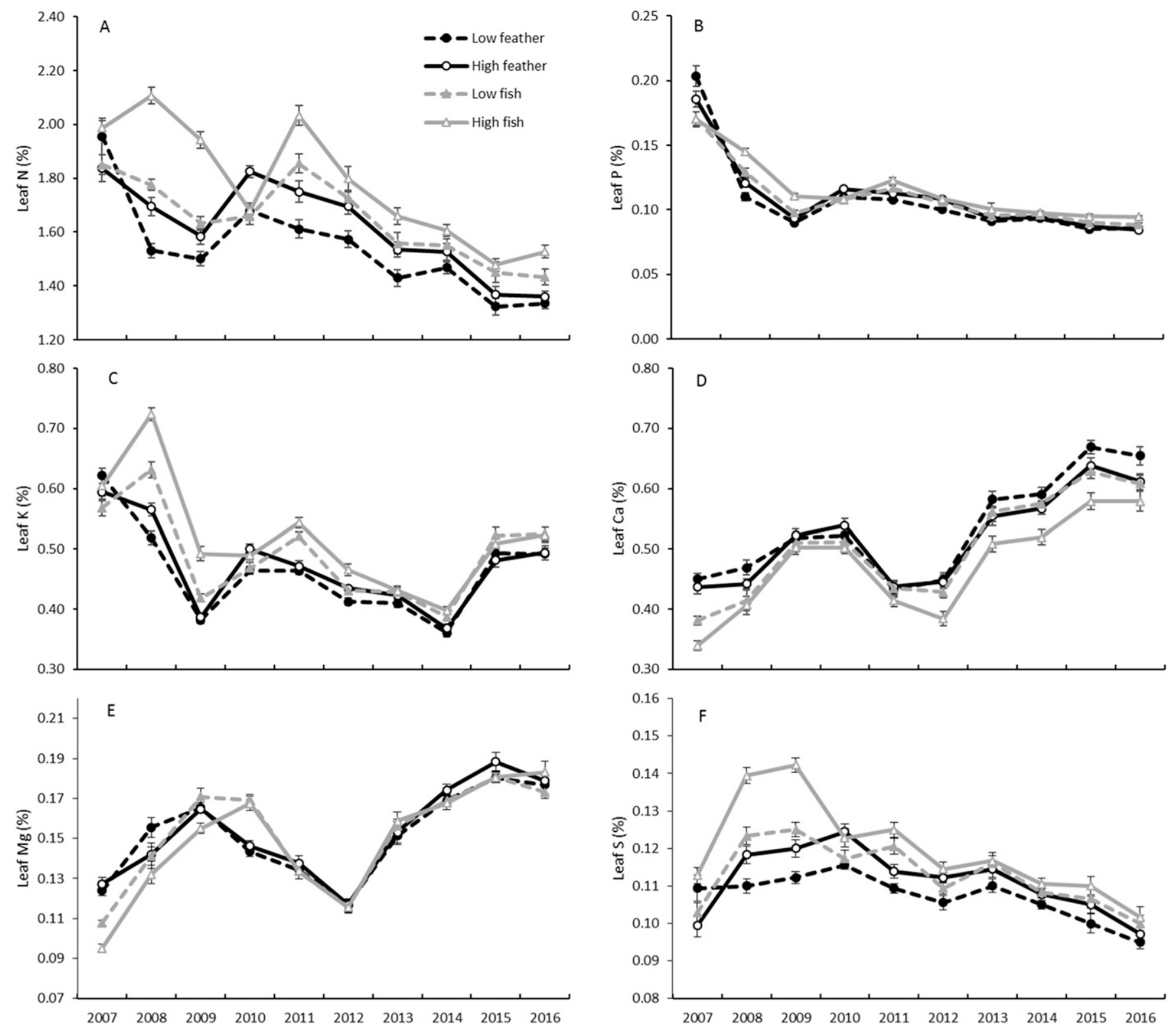

Fig. 4. Effect of fertilizing with low $\left(29-73 \mathrm{~kg} \cdot \mathrm{ha}^{-1} \mathrm{~N}\right.$ per year) or high $\left(57-140 \mathrm{~kg} \cdot \mathrm{ha}^{-1} \mathrm{~N}\right.$ per year) rates of feather meal or fish solubles in 'Liberty' northern highbush blueberry plants grown in a certified organic planting at Oregon State University's North Willamette Research and Extension Center from the first through the tenth growing season (2007-16) on leaf (A) N, (B) P, (C) K, (D) Ca, (E) Mg, and (F) S concentration. Means are averaged over planting method (raised beds and flat ground) and mulch (sawdust, compost + sawdust, and weed mat) treatments. Error bars represent $\pm 1 \mathrm{SE}$.

no difference between cultivars on flat ground (120 ppm, on average). Fertilization with the high rate of fish increased leaf $\mathrm{Mn}$ relative to the other fertilizer treatments in all but 2015 ('Liberty' only) and 2016. Leaf Mn was within published sufficiency levels (Hart et al., 2006) for all treatments in all years of the study.

Leaf $\mathrm{Fe}$ and $\mathrm{Al}$ concentrations were quite variable throughout the study period, ranging from 56 to $210 \mathrm{ppm}$ and 87 to $226 \mathrm{ppm}$, respectively, likely due to dust being on sampled leaves that were not washed (Hart et al., 2006; Strik and Vance, 2015). Leaf Cu was much higher in the first growing season (6 ppm) than in subsequent years (1.8-4.6 ppm), and 'Duke' had higher leaf $\mathrm{Cu}$ (3.4 ppm) than 'Liberty' in most years (averaging 2.7 ppm). 'Duke' had higher leaf Zn (12.4 ppm) than 'Liberty' (8.9 ppm) over the study period. Leaf $\mathrm{Zn}$ was within published sufficiency levels $(8-30 \mathrm{ppm})$, whereas leaf $\mathrm{Cu}$ was below sufficiency (5-15 ppm; Hart et al., 2006) for most treatments and years of the study.

\section{Relationships among soil and plant nutrients and yield}

Correlations between soil $\mathrm{pH}$ and leaf nutrients. Soil $\mathrm{pH}$ was negatively correlated to leaf Mn concentration in 6 out of the 10 years of the study and to leaf Al concentration in 2015 (data not shown).

Correlations between soil nutrients and nutrients in the plant leaves and fruit. Soil nutrient concentrations were usually uncorrelated with leaf nutrient concentrations in a given year. Exceptions included positive correlations between leaf $\mathrm{N}$ and soil $\mathrm{NO}_{3}-\mathrm{N}$ (2008-11, 2014) and $\mathrm{NH}_{4}-\mathrm{N}(2008,2010)$, leaf and soil P (2010, 2012, 2016), leaf and soil K (2008, 2011-13), and leaf and soil B (2015), and a negative correlation between leaf and soil Mg (2014) (data not shown). Fruit $\mathrm{K}$ concentration was also positively correlated to available soil $\mathrm{K}(\mathrm{r}=0.66 ; P=$ 0.002 ) in 'Duke' in 2015; however, there was no correlation between fruit and soil $\mathrm{K}$ in 2016 or for any other nutrient in the fruit and soil in either year that fruit were tested (data not shown).

Correlations between nutrients in the leaves and fruit. Leaf $\mathrm{K}$ was negatively correlated to leaf $\mathrm{Ca}$ from 2008 to 2014 in 'Duke' (Fig. 9A) and in 4 years of the study in 'Liberty' (Fig. 9B). Leaf K was also negatively correlated to leaf $\mathrm{Mg}$ in 4 years of the 

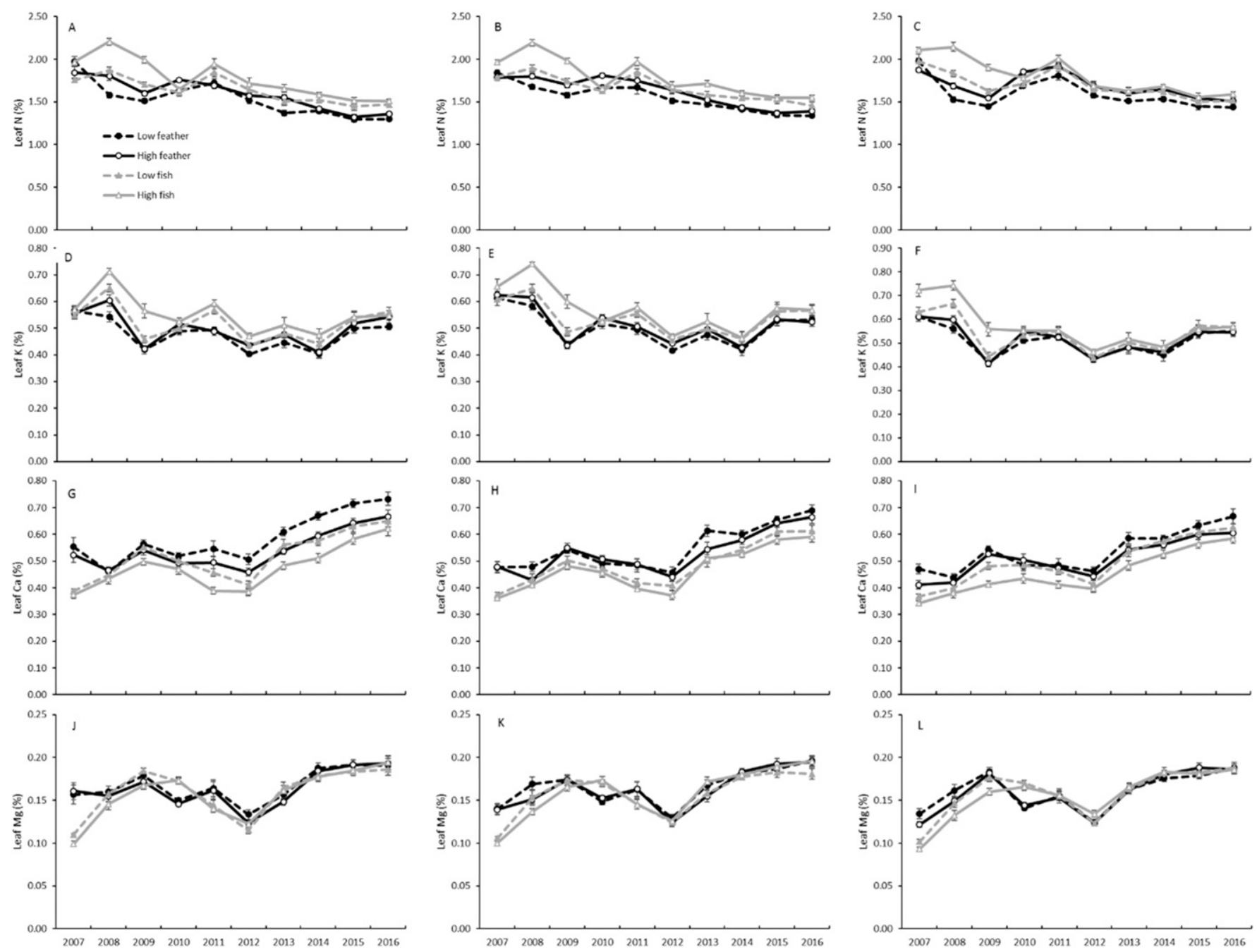

Fig. 5. Effect of fertilizing with low (29-73 $\mathrm{kg} \cdot \mathrm{ha}^{-1} \mathrm{~N}$ per year) or high $\left(57-140 \mathrm{~kg} \cdot \mathrm{ha}^{-1} \mathrm{~N}\right.$ per year) rates of feather meal or fish solubles when mulched with sawdust, yard-debris compost topped with sawdust (compost + sawdust) or weed mat for northern highbush blueberry plants grown in a certified organic planting at Oregon State University's North Willamette Research and Extension Center from the first through the tenth growing season (2007-16). Means are averaged over planting method (raised beds and flat ground) and cultivar (Duke and Liberty) treatments. Leaf N concentration for (A) sawdust, (B) compost + sawdust, and (C) weed mat; leaf K concentration for (D) sawdust, (E) compost + sawdust, and (F) weed mat; leaf Ca for (G) sawdust, (H) compost + sawdust, and (I) weed mat; and leaf $\mathrm{Mg}$ for $(\mathbf{J})$ sawdust, $(\mathbf{K})$ compost + sawdust, and (L) weed mat. Error bars represent \pm 1 sE.

study for both cultivars (data not shown). Leaf Ca was negatively correlated to leaf $\mathrm{Mg}$ in 4 years in both cultivars and negatively correlated to leaf $\mathrm{N}$ in 'Duke' (6 years) and 'Liberty' (3 years) (data not shown).

Fruit $\mathrm{Ca}$ concentration was positively correlated to leaf $\mathrm{Ca}$ in 'Duke' in $2015(\mathrm{r}=$ $0.66 ; P=0.02$ ) and negatively correlated to leaf $\mathrm{Ca}$ in 'Liberty' in $2016(\mathrm{r}=-0.064 ; P=$ 0.026). Furthermore, in 'Liberty', fruit $S$ was positively correlated to leaf $\mathrm{S}$ in $2015(\mathrm{r}=$ $0.69 ; P=0.014)$, whereas fruit $\mathrm{Mg}$ was correlated to leaf $\mathrm{Mg}$ in $2016(\mathrm{r}=0.73 ; P=$ 0.007).

Correlation between yield and soil $\mathrm{pH}$ and nutrients. In 'Duke', yield was negatively correlated to soil $\mathrm{pH}$ in $2008(\mathrm{r}=-0.35$; $P=0.0001)$, and positively correlated in 2010 $(\mathrm{r}=0.28 ; P=0.0021)$ and $2011(\mathrm{r}=0.36 ; P<$ $0.0001)$. Yield of 'Duke' was negatively correlated to several soil nutrient levels measured in the autumn of the same year, including $\mathrm{NO}_{3}-\mathrm{N}$ (2011-12) and $\mathrm{NH}_{4}-\mathrm{N}$ (2010), P (2013), K (2011-12, 2014), Ca and $\mathrm{Mg}$ (2008), Fe (2012), B (2010), Mn (2012), and Zn (2013) (data not shown). In contrast, yield was positively correlated to soil $\mathrm{K}$ and $\mathrm{B}$ measured in the same year in 2008 and soil Al in 2010 and 2012-13 (data not shown). Similar results were found when yield was compared with soil nutrient levels measured in autumn of the previous year, including negative correlations between yield and soil $\mathrm{NO}_{3}-\mathrm{N}(2009-10,2012)$ and $\mathrm{NH}_{4}-\mathrm{N}$ (2009), P (2009-12, 2013), K (201214), $\mathrm{Mg}$ (2014), Fe (2012-13), B (2012), Mn (2009, 2011, 2013), and Al (2012), and a positive correlation between yield and soil $\mathrm{Al}$ (2011, 2014); however, yield was positively correlated to soil $\mathrm{Ca}$ (2013) and Fe (2014) measured in the previous year (data not shown).

Correlations between leaf nutrients and yield. Leaf $\mathrm{N}$ was negatively correlated to yield (in the same year) in 2009, 2011 ('Liberty' only), and 2014 ('Duke' only), and positively correlated to yield in 2015 and 2016 ('Liberty' only) (Fig. 10A and B).
Leaf $\mathrm{P}$ was also negatively correlated to yield in 6 out of 9 years in 'Duke' and 3 out of 9 years in 'Liberty' and positively correlated to yield in 1 year in 'Duke (data not shown). The relationship between yield and leaf $\mathrm{K}$ was variable in 'Duke', with a positive correlation between the two variables during the first fruiting season in $2008(\mathrm{r}=0.271 ; P=0.026)$ and a negative correlation in $2009(\mathrm{r}=$ $-0.484 ; P<0.0001$; data not shown) and 2011-14 (Fig. 10C). In contrast, leaf $\mathrm{K}$ in 'Liberty' was negatively correlated to yield in 2011, and positively correlated to yield in 2015-16 (Fig. 10D). Leaf Ca in 'Duke' was positively correlated to yield in all years of the study except for 2008 (negatively correlated), but no correlation was found in ' $\mathrm{Lib}$ erty' in any year (data not shown). Leaf B was positively correlated to yield in 'Duke' in 2009-11 and in 'Liberty' in 2010 but was negatively correlated to yield in 'Duke' in 2008 and in 'Liberty' in 2012 and 2014 (data not shown). Leaf $\mathrm{Cu}$ was positively correlated to yield in both cultivars in 3 years of 

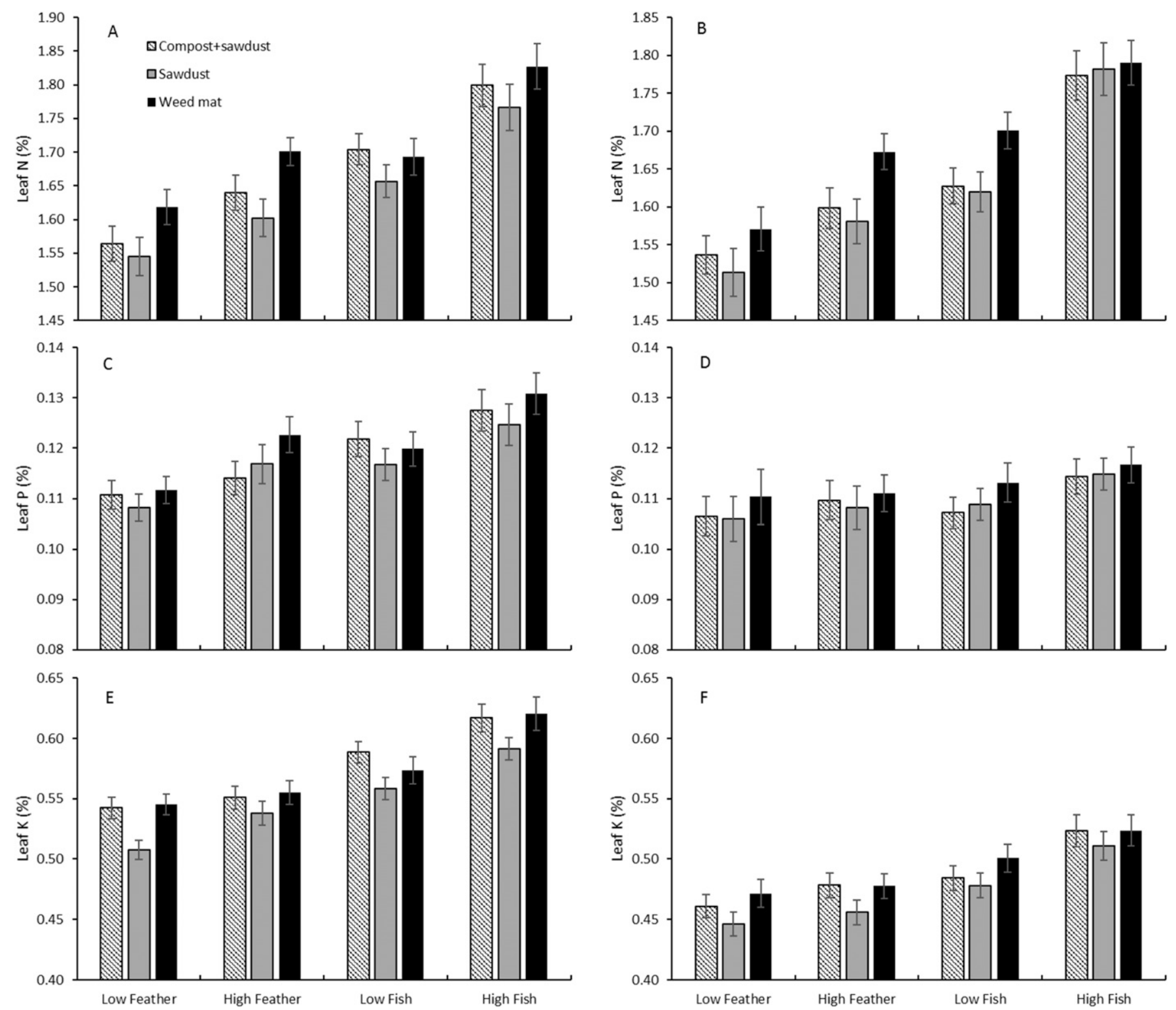

Fig. 6. Effect of fertilizing with low (29-73 kg.ha ${ }^{-1} \mathrm{~N}$ per year) or high $\left(57-140 \mathrm{~kg} \cdot \mathrm{ha}^{-1} \mathrm{~N}\right.$ per year) rates of feather meal or fish solubles when mulched with sawdust, yard-debris compost topped with sawdust (compost + sawdust) or weed mat on leaf N concentration in (A) 'Duke' and (B) 'Liberty', leaf P in (C) 'Duke' and (D) 'Liberty', and leaf K in (E) 'Duke' and (F) 'Liberty' for northern highbush blueberry plants grown in a certified organic planting at Oregon State University's North Willamette Research and Extension Center from the first through the tenth growing season. Means are averaged over planting method (raised beds and flat ground) and 10 years (2007-16). Error bars represent \pm 1 SE.

the study, as was leaf $\mathrm{Al}$ for 3 years in 'Liberty' and for 4 years in 'Duke' (data not shown).

\section{Discussion}

Mulch effects. In the later years of our study, soil organic matter was lowest with weed mat $(2.9 \%)$ and highest with compost + sawdust mulch (4.1\%). Organic soil amendments like compost that are resistant to decomposition, with a lower $\mathrm{C}: \mathrm{N}$ ratio, are better suited to building soil organic matter than sawdust (Crohn, 2016), as we found. Declines in organic matter under black weed mat have been reported in other perennial crops (Atucha et al., 2011; Choi et al., 2011; Neilsen et al., 2003b). Soil organic matter probably decomposes more rapidly under weed mat due to higher soil temperatures (Larco 2010; Strik et al., 2017a), as noted by others under black geo-textile or plastic (Cox, 2009; Runham et al., 2000; Strik et al., 2006). In general, higher levels of soil organic matter improve plant growth and yield in blueberry, but the presence of weeds in unmulched, control plots can confound the results (Clark and Moore, 1991; Goulart et al., 1997; Karp et al., 2006; Kozinski, 2006; Krewer et al., 2009; Savage, 1942; White, 2006). In this study, weeds were controlled in all treatments, allowing for a direct comparison of mulch effects (Strik, 2016; Strik et al., 2017a; Strik and Vance, 2017). Despite the measured differences in soil organic matter among the mulches in our trial, there was no impact on yield after 10 years (Strik et al., 2017a), indicating that all treatments were within an acceptable range for blueberry.

Yard-debris compost is relatively high in pH (Sullivan et al., 2015, 2018) and, therefore, increased soil $\mathrm{pH}$ relative to sawdust mulch in the present study. Other types of composts also increase soil $\mathrm{pH}$ in blueberry (Burkhard et al., 2009; Forge et al., 2013). Hence, the use of compost can mitigate the decline in soil $\mathrm{pH}$ that occurs with fertilization with ammonium sources of $\mathrm{N}$ over time (Larco et al., 2013a; Strik, 2016). Although soil $\mathrm{pH}$ varied with mulch treatment, all remained within the desirable range for blueberry (4.5-5.5; Hart et al., 2006), likely explaining why there was little correlation observed between soil $\mathrm{pH}$ and yield in this study. However, even though the range was narrow in this study, soil $\mathrm{pH}$ was negatively 

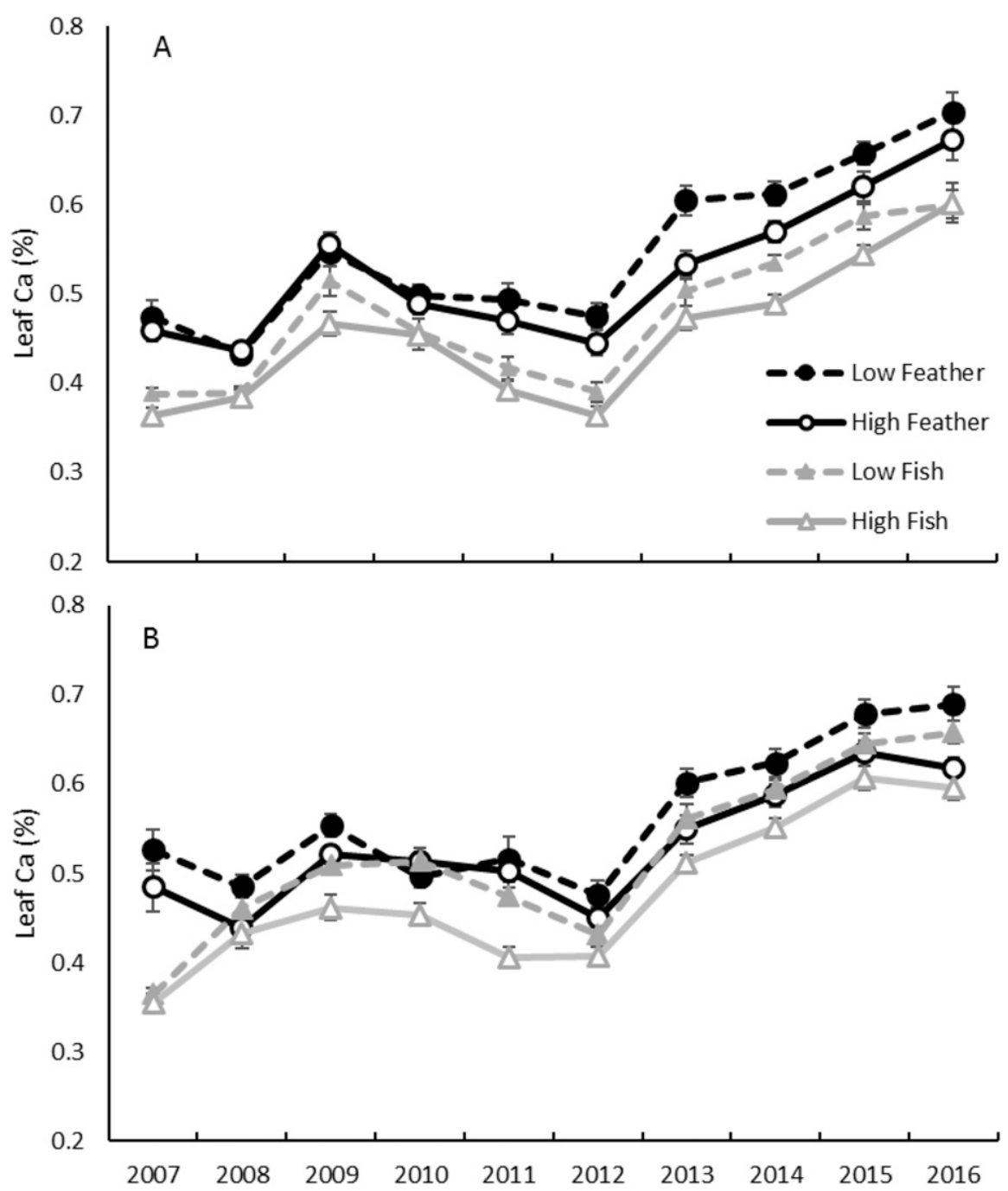

Fig. 7. Effect of fertilizing with low (29-73 kg.ha ${ }^{-1} \mathrm{~N}$ per year) or high $\left(57-140 \mathrm{~kg} \cdot \mathrm{ha}^{-1} \mathrm{~N}\right.$ per year) rates of feather meal or fish solubles on the Ca concentration of leaves sampled in late July to early August, depending on year, for northern highbush blueberry plants grown on (A) raised beds and (B) flat ground. The plants were grown in a certified organic planting at Oregon State University's North Willamette Research and Extension Center from the first through the tenth growing season (2007-16). Means are averaged over a combination of two cultivars (Duke and Liberty) and three mulch (sawdust, compost + sawdust, and weed mat) treatments. Error bars represent \pm 1 SE.

correlated to leaf $\mathrm{Mn}$ in 6 out of 9 years, confirming leaf testing is a useful tool for signaling soil $\mathrm{pH}$ changes over time (Strik and Vance, 2015; Strik et al., 2017b). Neilsen et al. (2003b) reported a positive correlation between cumulative yield of apple and soil $\mathrm{pH}$ and a negative correlation between yield and soil Mn.

Over the course of the study, from establishment of the planting in Oct. 2006 through the end of the tenth growing season in 2016, application of sawdust as a mulch added a cumulative total of $261,28,88$, and 217 $\mathrm{kg} \cdot \mathrm{ha}^{-1}$ of $\mathrm{N}, \mathrm{P}, \mathrm{K}$, and $\mathrm{Ca}$, respectively (Table 1). Yard-debris compost provided additional totals of 2274, 400, 961, and $2744 \mathrm{~kg} \cdot \mathrm{ha}^{-1}$ of each nutrient, respectively, compared to the use of sawdust mulch alone. Adding compost to the mulch increased the concentration of $\mathrm{K}$ in the soil by as much as $90 \%$ relative to sawdust only or weed mat (340-400 ppm and 200-240 ppm, on average, respectively) and increased soil $\mathrm{P}, \mathrm{Ca}$, bush blueberry (Burkhard et al., 2009; Neilsen et al., 2003a, 2007).

Leaf $P$ concentration also increased with addition of compost mulch when the plants were fertilized with fish solubles in 'Duke', but not in 'Liberty'. In apple (Malus ×pumila Mill.), a mulch of paper and biosolids increased leaf $P$ in most years of a 6-year study (Neilsen et al., 2003a), but Forge et al. (2013) reported no effect of a yard-debris compost on soil or leaf P levels of blueberry in a 3-year study.

Compared with other mulches, the use of sawdust mulch led to the lowest levels of soil $\mathrm{P}, \mathrm{K}, \mathrm{Mg}$, and $\mathrm{Ca}$ by the end of the study. The impact of sawdust mulch on leaf nutrient concentration relative to the other mulches varied with planting method and fertilizer treatment. For example, when the plants were grown on flat ground, leaf $\mathrm{Ca}$ was greater with sawdust mulch, on average, than with the other mulches in both cultivars, agreeing with Forge et al. (2013). When plants were young in this trial, mulching with sawdust reduced top growth and increased root growth relative to the other mulches (Larco et al., 2013a, 2013b), likely due to immobilization of $\mathrm{N}$ in the fertilizers reducing plantavailable $\mathrm{N}$ (White, 2006).

Compared with sawdust mulch, which was the industry standard when this study was initiated, weed mat increased soil $\mathrm{pH}$ and the level of soil $\mathrm{P}, \mathrm{K}, \mathrm{Ca}$, and $\mathrm{Mg}$ by the end of the study. In contrast, Choi et al. (2011) reported lower soil $\mathrm{pH}, \mathrm{P}, \mathrm{K}, \mathrm{Ca}$, and $\mathrm{Mg}$ under weed mat than wood chip mulch. In the present study, despite weed mat treatments receiving the same fertilizer as those mulched with sawdust, the soil under weed mat retained higher levels of the aforementioned nutrients likely in part due to less movement of these nutrients through the rooting zone with rainfall as compared with the organic mulches. In our climate, most rainfall occurs from October through May (U.S. Dept. of Interior, 2014). During the growing season, however, plots with weed mat required more irrigation each year (244-446 L/plant) than those mulched with sawdust to maintain a similar level of soil water content among the treatments (Strik et al., 2017a). A reduction in soil moisture under weed mat relative to organic mulch was also reported in apple (Choi et al., 2011).

We measured higher levels of soil $\mathrm{NO}_{3}-\mathrm{N}$ in plots with weed mat than those with other mulches, particularly on raised beds, which had higher soil temperatures than flat ground (Larco, 2010; Strik et al., 2017a). Choi et al. (2011) also measured higher $\mathrm{NO}_{3}-\mathrm{N}$ in weed mat plots compared with wood chip mulch. Higher levels of macronutrients in the soil under weed mat mulch led to corresponding increases in leaf $\mathrm{N}, \mathrm{P}$, and $\mathrm{K}$ (compared with sawdust mulch only) but had no effect on leaf $\mathrm{Ca}$ or $\mathrm{Mg}$. Increases in leaf $\mathrm{N}$ may have been related to increased uptake with greater top growth or canopy size, whereas increased leaf $\mathrm{P}$ may have been a result of improved soil temperature during periods of root growth (Bryla et al., 2017; Valenzuela-Estrada et al., 

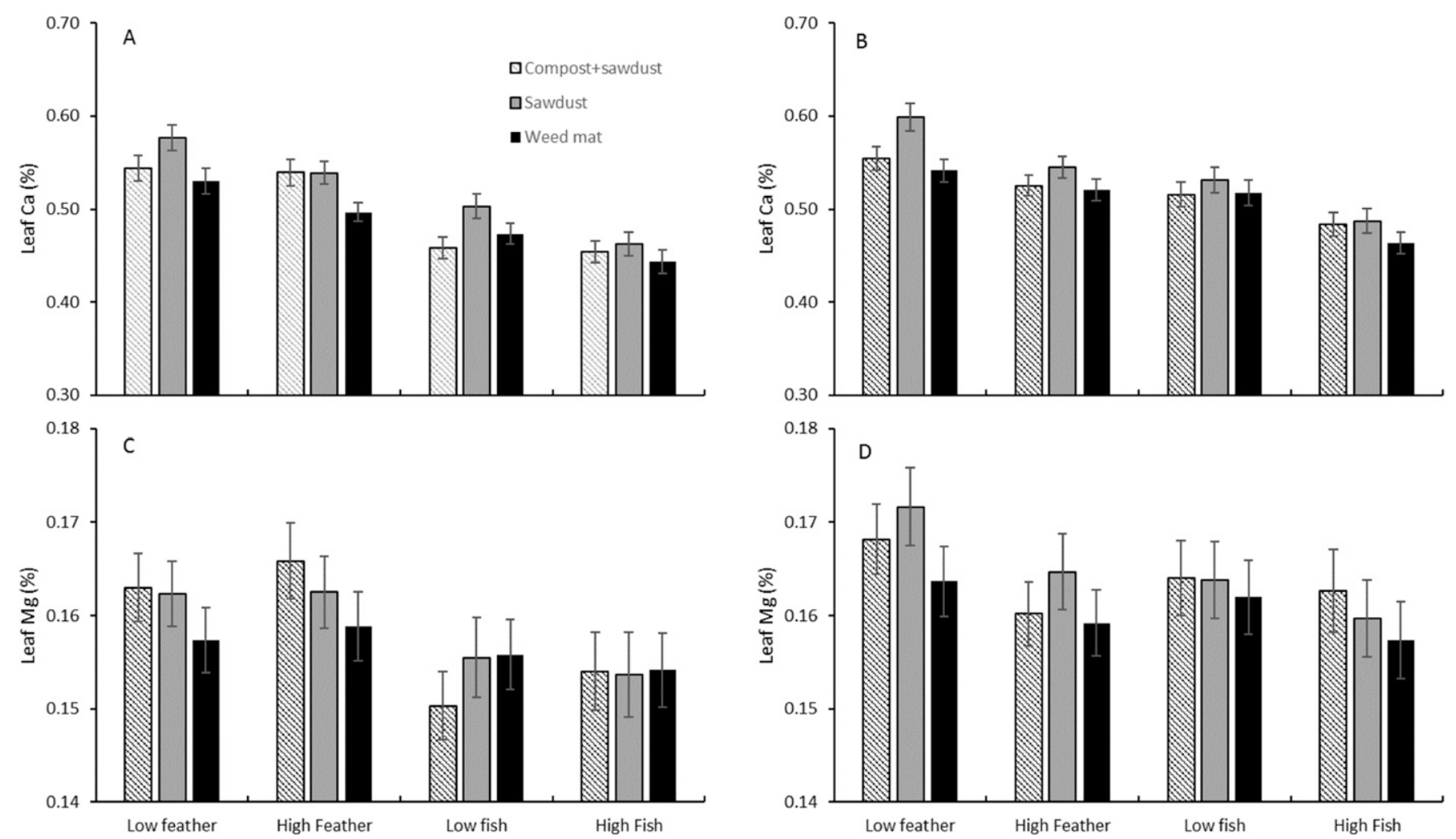

Fig. 8. Effect of fertilizing with low (29-73 kg.ha ${ }^{-1} \mathrm{~N}$ per year) or high $\left(57-140 \mathrm{~kg} \cdot \mathrm{ha}^{-1} \mathrm{~N}\right.$ per year) rates of feather meal or fish solubles when mulched with sawdust, yard-debris compost topped with sawdust (compost + sawdust) or weed mat on leaf Ca concentration for plants grown on (A) raised beds and (B) flat ground and leaf $\mathrm{Mg}$ concentration for plants grown on (C) raised beds and (D) flat ground. The northern highbush blueberry plants were grown in a certified organic planting at Oregon State University's North Willamette Research and Extension Center from the first through the tenth growing season. Means are averaged over a combination of two cultivars (Duke and Liberty) and 10 years (2007-16). Error bars represent \pm 1 SE.

2011). Despite high levels of soil $\mathrm{K}, \mathrm{Ca}$, and $\mathrm{Mg}$ under weed mat mulch, it is possible that the ratio of these nutrients was not ideal or that the levels were sufficient. Blueberry plants have a low requirement for $\mathrm{Ca}$ (Korcak, 1988). Plants grown with weed mat may have had more top growth than those grown with other mulches, diluting the concentration of $\mathrm{Ca}$ and $\mathrm{Mg}$ in leaves, as was reported in cherry (Prunus avium L.; Yin et al., 2007). Weed mat mulch improved top growth of the plants during establishment (Larco et al., 2013a) and led to a 11\% higher cumulative yield than the organic mulches during the study period, but only in 'Liberty' (Strik et al., 2017a). Krewer et al. (2009) reported that rabbiteye blueberry ( $V$. virgatum Ait.) plants had greater leaf $\mathrm{N}$ with weed mat than sawdust mulch in the first year after planting only, and thereafter, the opposite was found. However, in their study, plants grown with weed mat had a lower yield.

The addition of compost or biosolids to a mulching program often increases soil and leaf $\mathrm{K}$ of blueberry and other crops (Burkhard et al., 2009; Forge et al., 2013; Neilsen et al., 2003a; 2007). In the present study, soil K increased with planting age and was positively correlated with leaf $\mathrm{K}$ concentration. However, both soil and leaf $\mathrm{K}$ levels were negatively correlated to yield in 3 and 5 out of 9 years, respectively, in 'Duke'. While some suggest that yield should be considered when interpreting leaf $\mathrm{K}$ concentration (e.g., Eck,
1988; Retamales and Hancock, 2012), because fruit are high in K (e.g., Strik and Vance, 2015), we found no evidence of this in these cultivars nor have others (Eck, 1988; Hancock and Nelson, 1988). Eck (1983) found that yield was positively correlated to soil $\mathrm{K}$ in a 10-year study on 'Bluecrop' blueberry, and when he applied various rates of $\mathrm{K}$ fertilizer, the highest yield was found when leaf $\mathrm{K}$ was between $0.45 \%$ and $0.55 \%$. In that study, the plants may have responded positively to $\mathrm{K}$ fertilizer because soil $\mathrm{K}$ was relatively low at the site. Hancock and Nelson (1988) reported an optimal leaf K of $0.43 \%$. In our study, we found the highest yields at leaf $\mathrm{K}$ concentrations ranging from $0.42 \%$ to $0.55 \%$, although concentrations as high as $0.67 \%$ were measured.

Although ideal ratios of cations are promoted by some analysis laboratories, advisors, or consultants, neither our findings nor the data of others (Kopittke and Menzies, 2007) support this concept. Despite higher levels of $\mathrm{Mg}$ and $\mathrm{Ca}$ in the soil with addition of compost to the mulch, there was no increase in leaf $\mathrm{Mg}$ or $\mathrm{Ca}$ in the present study. In apple, biosolids and paper mulch increased soil $\mathrm{Ca}$ and $\mathrm{Mg}$, as well as leaf $\mathrm{Ca}$ (Neilsen et al., 2003a). In our study, the ratios of $\mathrm{Ca}: \mathrm{K}$ and $\mathrm{Mg}: \mathrm{K}(\mathrm{ppm})$ were reduced to 5.8 and 1.5 , respectively, when compost was added to the mulching program. Gough (1994) considered a Ca:K ratio of 5 to be desirable for blueberry. However, we found that soil $\mathrm{Ca}: \mathrm{K}$ ratios more than 5.8 to 6.3 (ppm; measured in compost + sawdust or with the high rate of fish) were associated with the lowest yields, whereas ratios of 8.3 to 8.8 (measured with weed mat mulch or with feather meal) led to the highest yield.

Several studies have reported that high levels of soil $\mathrm{K}$ reduce leaf $\mathrm{Ca}$ and $\mathrm{Mg}$ in blueberry (Eck, 1988; Fageria, 2001; Krewer and Ruter, 2012). We also found that high soil $\mathrm{K}$ reduced leaf $\mathrm{Ca}$ and noted negative correlations between these variables in 7 out of 9 years in 'Duke' and 4 years in 'Liberty'. Leaf $\mathrm{Ca}$, on the other hand, was positively correlated to yield in all but one year of the study in 'Duke', as well as in a previous study by Eck (1977). The relationship between leaf $\mathrm{Ca}$ and yield in 'Duke' was likely a function of soil $\mathrm{K}$ and its negative impact on Ca uptake in blueberry. High soil $\mathrm{K}$ also reduced leaf $\mathrm{Mg}$ in 4 out of 9 years in both cultivars.

Raised beds vs. flat ground. Plants grown on raised beds had higher leaf N, P, and $\mathrm{K}$, and lower $\mathrm{Ca}, \mathrm{Mg}$, and $\mathrm{B}$, on average, than when plants were grown on flat ground. Leaf $\mathrm{Ca}$ and $\mathrm{Mg}$ may have been lower on raised beds (despite higher soil $\mathrm{Ca}$ and $\mathrm{Mg}$, depending on fertilizer source), because the plants had more top growth [measured during establishment (Larco et al., 2013a) and evidenced by higher yield (Strik et al., 2017a)] and, therefore these nutrients were diluted in the leaves. Although soil $\mathrm{P}$ was unaffected by planting method and levels of $\mathrm{P}$ in soil were 

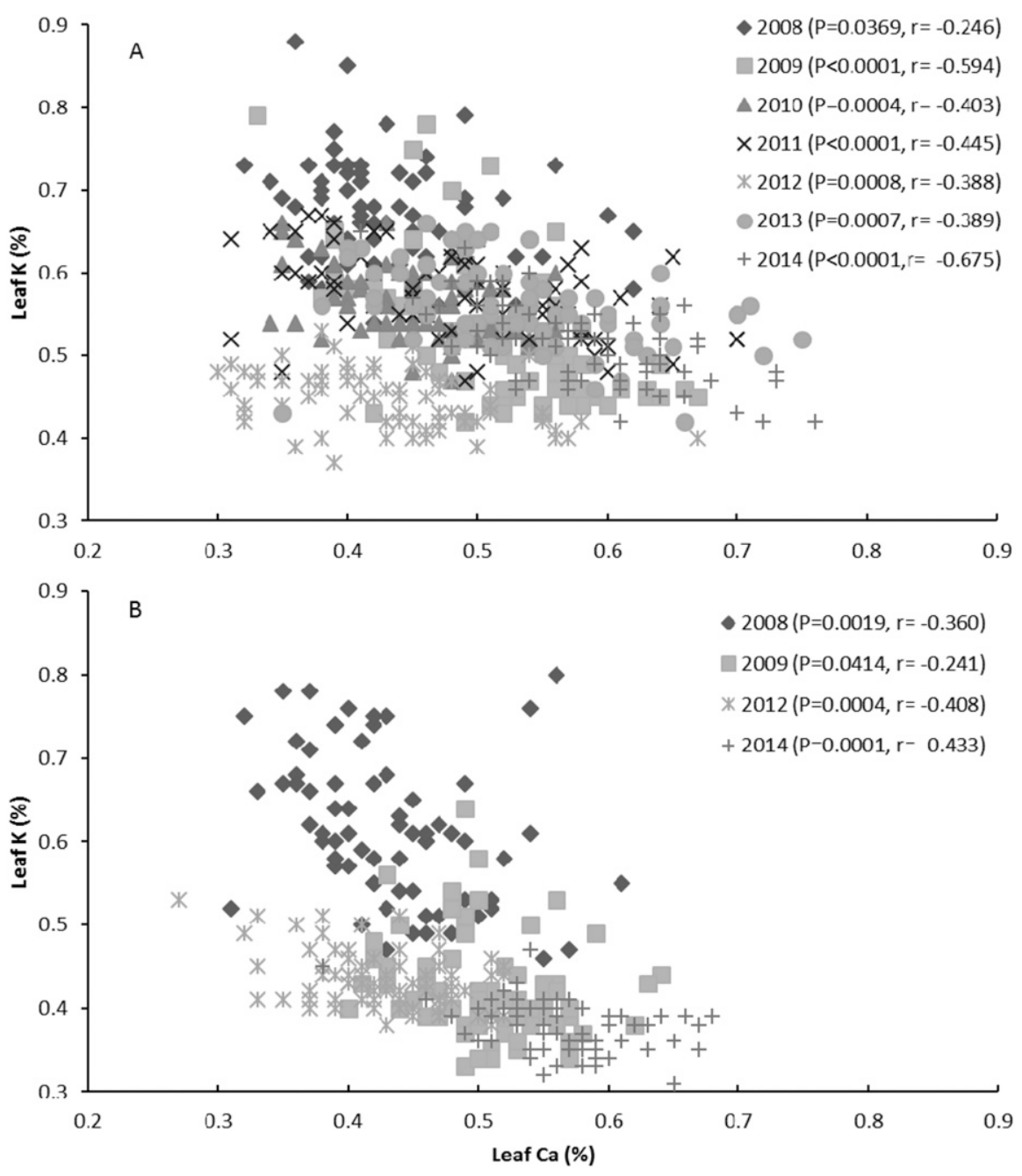

Fig. 9. Relationship between leaf $\mathrm{K}$ and $\mathrm{Ca}$ concentration for 'Duke' (A) and 'Liberty' (B) northern highbush blueberry plants grown in a certified organic planting at Oregon State University's North Willamette Research and Extension Center. Each point represents the leaf nutrient concentration in the same year for a plot. Only years with a significant correlation are shown $(P<0.05)$. Actual $P$ values and Pearson's correlation coefficients are given in the legend.

sufficient in all treatments, improved root growth on raised beds (Bryla et al., 2017; Valenzuela-Estrada, et al., 2011) likely increased leaf $\mathrm{P}$ as well as the other aforementioned nutrients.

Fertilizer source and rate. We previously reported that cumulative yield (2008-16) in this trial was $10 \%$ greater with feather meal than with fish solubles, on average, and $4 \%$ greater with the low rate than with the high rate of $\mathrm{N}$ fertilizer (Strik et al., 2017a). 'Duke' was particularly sensitive to fertilizer source, producing $35 \%$ less yield overall with fish solubles than with feather meal. In contrast, there was relatively little effect of fertilizer source or rate on yield in 'Liberty'. Here, we show evidence that the high rate of $\mathrm{N}$ was in excess of the nutrient needs of the plants. Fertilizing with the high rate of $\mathrm{N}$ throughout the study period (Table 2) increased soil $\mathrm{NO}_{3}-\mathrm{N}$ level, particularly when using fish solubles (with sawdust or compost + sawdust mulch) or with feather meal (with weed mat mulch). Soil $\mathrm{NH}_{4}-\mathrm{N}$ was also high when fertilizing with fish solubles and mulching with weed mat. Leaf $\mathrm{N}$ concentration was higher when fertilizing with fish solubles, particularly at the high rate in all mulch treatments when plants were young, and at either rate throughout the study in the sawdust or compost + sawdust mulches. Nitrogen in the fish solubles may have been more available in the sawdust or compost + sawdust mulches than the granular source of feather meal, as both fertilizers were applied on top of the mulches. In contrast, the weed mat was opened before applying the granular feather meal and the drip irrigation underneath the weed mat coupled with increased temperatures (Larco 2010; Strik et al., 2017a) may have increased the availability of $\mathrm{N}$ in the feather meal, leading to fewer effects of fertilizer source on leaf $\mathrm{N}$ in this mulch treatment. We also found that when feather meal was first applied in early April of the first growing season (2007), plants showed symptoms of $\mathrm{N}$ deficiency, and growth was reduced (Larco et al., 2013a, 2013b). Most fertilizer $\mathrm{N}$ is acquired during shoot and fruit development (Bañados, 2006; Bañados et al.,
2012; Retamales and Hanson, 1989; Throop and Hanson, 1997), thus fertilizer $N$ must be applied early enough to be available to the plant when needed. When the first application of feather meal was applied earlier (early March) of the following years (2008-16), no symptoms of $\mathrm{N}$ deficiency were observed (Larco et al., 2013a, 2013b; Strik et al., 2017a). However, leaf $\mathrm{N}$ concentration was still lower with feather meal than with fish solubles in many years. Nitrogen applied through fertigation, as was done with the fish solubles in our study, has been shown to be more readily available than granular sources in blueberry (Bryla and Machado, 2011). Furthermore, feather meal was applied in the split applications in early March and early May each year, whereas the fish solubles were applied by fertigation every 2 weeks from mid April to early July, likely increasing availability of $\mathrm{N}$ in the root zone.

Higher rates of $\mathrm{N}$ fertilizer application, regardless of source, increased leaf $\mathrm{N}$, thus confirming what has been reported in conventional production systems in blueberry (Bañados, 2006; Bañados et al., 2012; Bishop et al., 1971; Cummings et al., 1971; Eck, 1977; Spiers, 1983; Townsend, 1973). However, the higher leaf $\mathrm{N}$ measured with fish solubles did not result in a higher yield. Across all fertilizer treatments, there was no consistent relationship between yield and leaf $\mathrm{N}$ concentration in the same year over the study period.

Higher rates of $\mathrm{N}$ fertilizer increased fruit $\mathrm{N}$ concentration of 'Wolcott' (Ballinger and Kushman, 1966), but no such response was found in six cultivars of highbush blueberry grown conventionally in Oregon (Strik and Vance, 2015). Although the fruit $\mathrm{N}$ concentration varied between years in certified organic blueberry in Oregon, there was no cultivar (six studied) by year interaction, and the plantings were fertilized at the same rate of $\mathrm{N}$ between years (Strik and Vance, 2015). In this study, we found no consistent relationship between the concentration of $\mathrm{N}$ in the fruit and leaves. In contrast, Ballinger and Kushman (1966) found that increased yield reduced leaf and fruit $\mathrm{N}$ concentration.

These organic fertilizers also contain many nutrients other than N. For example, fertilization with the high rate of fish solubles increased the application of $\mathrm{P}, \mathrm{K}$, and $\mathrm{Mg}$ by 161,663 , and $25 \mathrm{~kg} \cdot \mathrm{ha}^{-1}$, respectively, and decreased $\mathrm{Ca}$ by $79 \mathrm{~kg} \cdot \mathrm{ha}^{-1}$ compared with same rate of feather meal over the whole study period (Table 2). Although the fish solubles contained high levels of $\mathrm{Na}(1.9 \%$ to $2.2 \%)$ and had an EC of $20-25 \mathrm{dS} \cdot \mathrm{m}^{-1}$, the product was diluted before application to reduce the EC to levels well below the $2 \mathrm{dS} \cdot \mathrm{m}^{-1}$ threshold reported by Bryla and Machado (2011), as confirmed by measurements of the soil solution during the study (Valenzuela-Estrada, unpublished data).

Fertilization with the high rate of fish solubles increased leaf $\mathrm{P}$ concentration during many years of the study. Although higher rates of fertilizer $\mathrm{N}$ have been shown to 

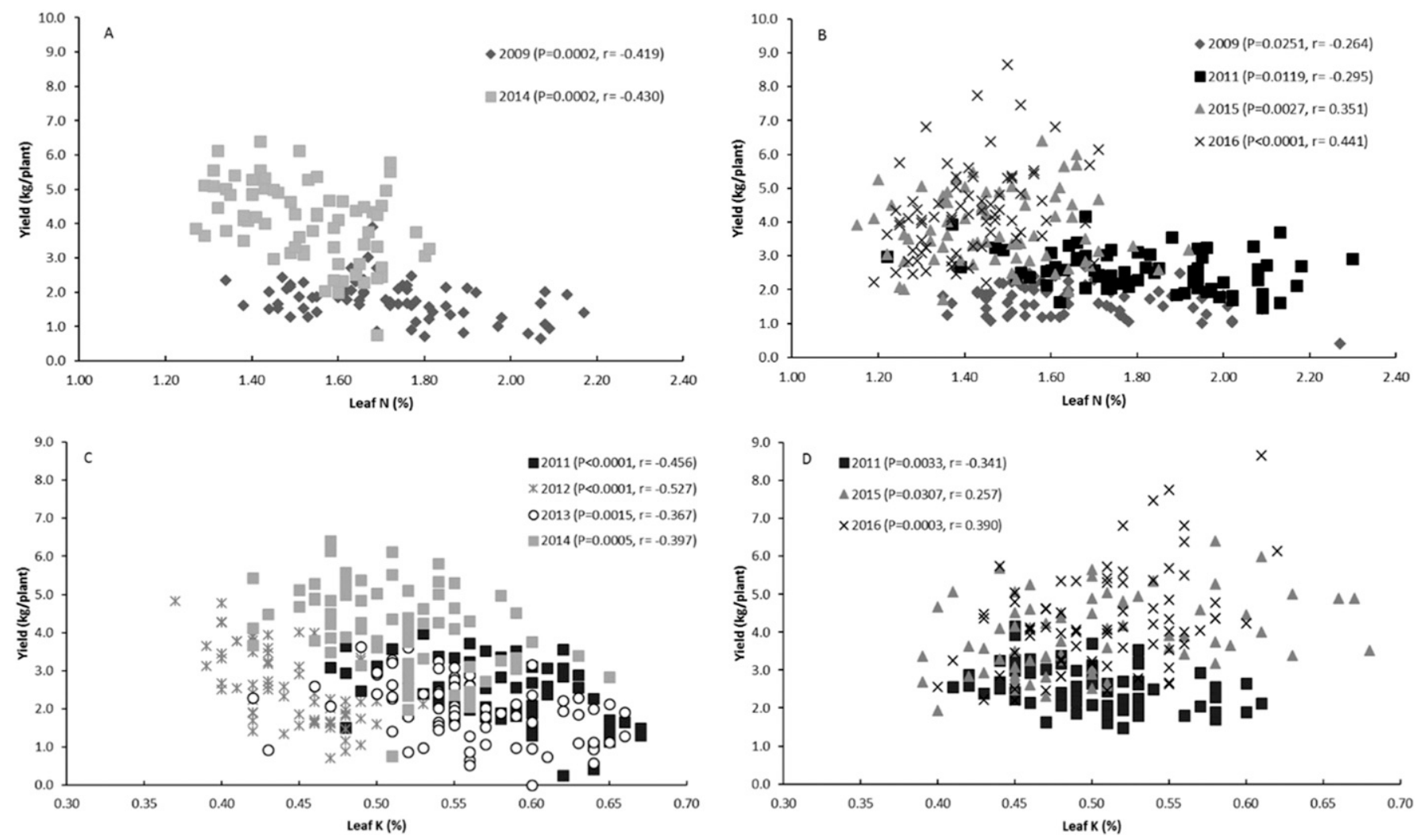

Fig. 10. Relationship between yield per plant and leaf N concentration for 'Duke' (A) and 'Liberty' (B) and leaf K concentration for 'Duke' (C) and 'Liberty' (D) northern highbush blueberry plants grown in a certified organic planting at Oregon State University's North Willamette Research and Extension Center. Each point represents the yield and leaf nutrient concentration in the same year for a plot. Only years with a significant correlation are shown $(P<0.05)$. Actual $P$ values and Pearson's correlation coefficients are given in the legend.

increase leaf $\mathrm{P}$ in conventional production systems (Bryla et al., 2012; Spiers, 1983), we did not observe this response with feather meal, which contained very little $P$.

Although the use of fish solubles at either rate increased soil $\mathrm{K}$ during most of the study period, there was no consistent relationship between the rate or source of fertilizer nutrient applied and soil $\mathrm{Ca}, \mathrm{Mg}$, and B. Fertilizing with fish solubles and mulching with compost + sawdust led to the highest soil $\mathrm{K}$. Perhaps, the main reason why 'Duke' did not yield well when fertilized with fish solubles was the high amount of $\mathrm{K}$ in the product. High levels of soil $\mathrm{K}$ from the fertilizer led to increased leaf $\mathrm{K}$ and reduced leaf $\mathrm{Ca}$ and $\mathrm{Mg}$ concentrations in both cultivars. The negative correlation between yield and leaf $\mathrm{K}$ (and correlated impacts) was more prevalent in 'Duke' than in 'Liberty', but the direct reasons for the difference between the cultivars are not known.

Feather meal was a good source of $\mathrm{Ca}$ for the plants and increased leaf $\mathrm{Ca}$ relative to using fish solubles. Growers are very interested in increasing fruit $\mathrm{Ca}$ to improve berry firmness (Saure, 2005; Van-Buren, 1979) and often assess leaf $\mathrm{Ca}$ concentration as an indicator of potential fruit quality. Although Strik and Vance (2015) found considerable variation in leaf and fruit $\mathrm{Ca}$ concentrations, there did not appear to be a relationship in these values for either cultivar. In addition, foliar applications of $\mathrm{Ca}$ at manufacturer recommended rates have not been found effective to increase fruit $\mathrm{Ca}$ concentration (Arrington and DeVetter, 2017; Vance et al., 2017), likely due to the relatively short time that stomates are functional in blueberries and the impact on $\mathrm{Ca}$ uptake through the xylem (via transpiration) in the fruit (Yang, 2018). Although the use of feather meal increased fruit $\mathrm{Ca}$ concentration in this trial relative to fish solubles (Fernandez-Salvador, unpublished data), the relationship between leaf and fruit $\mathrm{Ca}$ concentrations was inconsistent with both negative and positive correlations in 'Liberty' and 'Duke', respectively, in 1 out of 2 years.

Leaf $\mathrm{Ca}$ was negatively correlated to leaf $\mathrm{N}$ in many years of the study, perhaps because more $\mathrm{Ca}$ was applied with feather meal than with the fish solubles, whereas the latter source increased leaf N. Leaf $\mathrm{Ca}$ increased with plant age from establishment to maturity in both cultivars, but leaf $\mathrm{N}$ concentration was higher in young plants than mature plants. Conventional blueberry studies showed that leaf $\mathrm{Ca}$ declined with higher rates of $\mathrm{N}$ application, but that the leaf $\mathrm{N}$ increased (Bishop et al., 1971; Eck, 1977; Spiers, 1983; Townsend, 1973). In contrast, leaf $\mathrm{Ca}$ increased with rate of $\mathrm{N}$ fertilization in 1 year of a 2-year study of conventionallygrown 'Bluecrop' in Oregon (Bryla et al., 2012), likely due to decreased plant growth at the highest rates of $\mathrm{N}$ fertilizer applied and associated higher leaf $\mathrm{Ca}$.
Boron application was increased over the course of the study when fish solubles were used as a fertilizer source. Compared with feather meal, fertilizer source only affected leaf $\mathrm{B}$ when plants were young, and in those years, leaf B concentration was higher with feather meal. Bryla et al. (2012) reported that higher rates of $\mathrm{N}$ application reduced leaf $\mathrm{B}$ in 1 of 2 years. There were no consistent fertilizer source or rate effects on leaf $\mathrm{Cu}$ or $\mathrm{Zn}$ in either cultivar, despite large differences between the products and rates used.

Fertilization with the high rate of either source significantly reduced soil $\mathrm{pH}$ over the course of the study. This effect could cause low $\mathrm{pH}$ issues in a longer-term planting. Fertilization with the high rate of fish solubles, in particular, increased leaf Mn, likely a response to the lower soil $\mathrm{pH}$.

Cultivar. Cultivar had a large impact on leaf nutrient concentration, with 'Liberty' having lower levels of N, P (most years), K, $\mathrm{Ca}$ (although dependent on mulch treatment), $\mathrm{Mg}, \mathrm{S}, \mathrm{B}, \mathrm{Cu}, \mathrm{Zn}$, and $\mathrm{Al}$ and higher levels of $\mathrm{Fe}$ and Mn than 'Duke', on average, and had higher yield (Strik et al., 2017a). Our results confirm the importance of leaf tissue sampling cultivars separately when assessing plant nutrient status (Hart et al., 2006; Strik and Vance, 2015).

Leaf nutrient testing. Although leaf analysis is a common practice to assess plant nutrient status and adjust fertilizer programs, as needed, the only consistent association 
with yield over the length of this study was for leaf $\mathrm{Ca}$ (positive) and $\mathrm{P}$ and $\mathrm{K}$ (negative) in 'Duke'. Despite having typical commercial yields, particularly for the best production system treatments (Strik et al., 2017a), leaf $\mathrm{N}$ and $\mathrm{P}$ were below published sufficiency levels in many years of our study (Hart et al., 2006). However, leaf $P$ was positively correlated to yield for 3 years only in 'Liberty' and was negatively correlated to yield in most years of the study in 'Duke'. In addition, despite the negative correlation between leaf $\mathrm{K}$ concentration and yield, particularly in 'Duke', leaf $\mathrm{K}$ was only above current sufficiency levels in 1 year for both cultivars (2008) and was below sufficiency in 'Liberty' in 1 year. Although higher concentrations of leaf $\mathrm{K}$ were correlated with lower leaf $\mathrm{Ca}$ and $\mathrm{Mg}$, these latter nutrients were only below sufficiency levels in one of the study years. Strik and Vance (2015) proposed that the sufficiency levels for $\mathrm{N}$ and $\mathrm{P}$ could be lowered, without negative effect on plant performance, in organic production systems as compared with conventional. They also suggested that the current leaf concentration standards for K may need to be reduced based on levels commonly measured in highperforming commercial fields. Our results here confirm these recommendations, particularly to reduce the risk of growers applying excess $\mathrm{K}$ fertilizer to achieve higher leaf $\mathrm{K}$ levels and considering the negative impact this may have on yield and potentially uptake of other cations.

Leaf B concentrations were below sufficiency levels the entire study period, despite sufficient or close to sufficient levels of soil B and application of additional fertilizer $\mathrm{B}$ as a granular to the soil and as a foliar product just before bloom according to the recommended practice (Hart et al., 2006). Although sufficient plant levels of $B$ are thought to be critical for good pollination and fruit or seed set, frequent applications of foliar B, while improving leaf and fruit $\mathrm{B}$ concentrations in some cases, had no impact on fruit set or yield in Washington (Arrington and DeVetter, 2017). In our study, leaf B was not consistently related to yield. Leaf and soil $\mathrm{Cu}$ levels were below sufficiency (Hart et al., 2006; Horneck et al., 2011) in most years of the study. Strik and Vance (2015) speculated that the sufficiency levels for $\mathrm{Cu}$ may have been originally established as higher than needed due to common use of $\mathrm{Cu}$ fungicides in blueberry. Copper fungicides were not needed or used during this study.

\section{Conclusions}

Testing these various production systems in a long-term certified organic trial from planting to maturity validated that establishing blueberry plants on raised beds rather than flat ground is critical for maximizing plant growth (Larco et al., 2013a) and yield (Strik et al., 2017a). Plants on raised beds have better root growth (Bryla et al., 2017; Valenzuela-Estrada, et al., 2011) and, as shown here, improved plant nutrient status.
Choice of a mulch is also important, both economically and for weed control. Weed mat mulch was the most economic method of controlling weeds (Strik and Vance, 2017) and increased cumulative yield as much as $11 \%$ (Strik et al., 2017a). However, disadvantages of using weed mat include increased irrigation requirement and presence of voles (Microtus sp.) (Strik et al., 2017a), and the significant decrease in soil organic matter reported here. Although the organic matter had not been reduced to a level detrimental to yield (through 2016), this is of concern for longer-term production. Adding a layer of sawdust under the weed mat showed great promise for mitigating some of these negative effects of weed mat mulch alone in organic production (Strik et al., 2017b) and is showing positive results for plant growth and early production during blueberry plant establishment in conventional production (Strik, unpublished data).

Organic growers like to use compost as a slow-release source of $\mathrm{N}$; however, having a yard-debris compost regularly applied to the planting, as was done here with compost + sawdust, may not be a sustainable option. As a mulch, compost topped with sawdust added considerable weed management costs compared with sawdust mulch alone (Strik and Vance, 2017). Although the addition of yarddebris compost to the mulch improved the level of soil organic matter compared with sawdust mulch alone, the compost increased soil $\mathrm{K}$, leading to increased leaf $\mathrm{K}$ and decreased leaf $\mathrm{Ca}$ and $\mathrm{Mg}$.

Plants in our study performed better ('Duke') or similarly ('Liberty') when fertilized with the lower rate of $\mathrm{N}$ than with the higher rate (Strik et al., 2017a). Fertilization with fish solubles, the most common fertilizer source used in organic blueberry plantings when the study began (Strik, 2016), led to higher K levels, decreasing yield of 'Duke'. Considering the high cost of these organic fertilizers (Strik et al., 2017a), our current N rate recommendations (Hart et al., 2006) may be reduced in organic production, particularly when using a high proportion of fertilizer sources containing $\mathrm{K}$ as well as $\mathrm{N}$.

It is clear in these organic production systems that assessing plant nutrient status and management of fertility programs is complicated. There were large interactions among treatments, indicating that making broad or general recommendations for growers is not advisable. For example, the mulch used affected plant response to fertilizer source and rate, and cultivars differed in their response. 'Duke' was particularly sensitive to fertilization with high rates of fish solubles. Because organic fertilizer sources of $\mathrm{N}$ most typically contain other nutrients, our study illustrates the importance of careful fertility management to avoid nutrient imbalances. Fertilizers and composts should be carefully chosen and likely changed over time to avoid large shifts in soil or nutrient availability. Although soil and leaf tissue testing are important to help manage fertilizer programs, the lack of a consistent relation- ship between soil and plant nutrient status and yield was a reflection of the complicated interactions that occurred among nutrients in these organic production systems. Clearly, careful observations of plant growth and yield and awareness of some of the pitfalls associated with long-term use of composts and a particular fertilizer source are important.

\section{Literature Cited}

Atucha, A., I.A. Merwin, and M.G. Brown. 2011. Long-term effects of four groundcover management systems in an apple orchard. HortScience 46:1176-1183.

Arrington, M. and L.W. DeVetter. 2017. Foliar applications of calcium and boron do not increase fruit set or yield in northern highbush blueberry (Vaccinium corymbosum). HortScience 52:1259 1264.

Ballinger, W.E. and L.J. Kushman. 1966. Factors affecting the mineral-element content of leaves and fruit of Wolcott blueberries. Proc. Amer. Soc. Hort. Sci. 88:325-330.

Bañados, M.P. 2006. Dry weight and ${ }^{15} \mathrm{~N}$-nitrogen and partitioning, growth, and development of young and mature blueberry plants. Ore. State. Univ., Corvallis, PhD Diss. 9 Apr. 2019. $<$ http://ir.library.oregonstate.edu/xmlui/handle/ 1957/9649>.

Bañados, M.P., B.C. Strik, D.R. Bryla, and T.L. Righetti. 2012. Response of highbush blueberry to nitrogen fertilizer during field establishment, I. Accumulation and allocation of fertilizer nitrogen and biomass. HortScience 47:648-655.

Bishop, R.F., L.R. Townsend, and D.L. Craig. 1971. Effect of source and rate of $\mathrm{N}$ and $\mathrm{Mg}$ on nutrient levels in highbush blueberry leaves and fruit. HortScience 6:37-38.

Bryla, D.R., B.C. Strik, M.P. Bañados, and T.L. Righetti. 2012. Response of highbush blueberry to nitrogen fertilizer during field establishment-II. Plant nutrient requirements in relation to nitrogen fertilizer supply. HortScience 47:917-926.

Bryla, D.R. and R.M.A. Machado. 2011. Comparative effects of nitrogen fertigation and granular fertilizer application on growth and availability of soil nitrogen during establishment of highbush blueberry. Frontiers Crop Sci. Hort. 2:1-8.

Bryla, D.R., L.R. Valenzuela-Estrada, and O.L. Vargas. 2017. Root production, distribution, and turnover in conventional and organic northern highbush blueberry systems. Acta Hort. 1180:169-175.

Burkhard, N., D. Lynch, D. Percival, and M. Sharifi. 2009. Organic mulch impact on vegetation dynamics and productivity of highbush blueberry under organic production. HortScience 44:688-696.

Chandler, R.B. and E.C. Mason. 1942. The effect of mulches on soil moisture, soil temperature, and growth of blueberry plants. Proc. Amer. Soc. Hort. Sci. 40:335-337.

Choi, H.-S., C.R. Rom, and M. Gu. 2011. Plant performance, and seasonal soil and foliar nutrient variations in an organic apple orchard under four ground cover management systems. J. Amer. Pomol. Soc. 65:130-146.

Clark, J.R. and J.N. Moore. 1991. Southern highbush blueberry response to mulch. HortTechnology $1: 52-54$.

Costello, R.C., D.M. Sullivan, D.R. Bryla, B.C. Strik, and J.S. Owen. 2019. Compost feedstock and compost acidification impact growth and mineral nutrition in northern highbush blueberry. HortScience 54:1067-1076. 
Cox, J. 2009. Comparison of plastic weedmat and woodchip mulch on low chill blueberry soil in New South Wales, Australia. Acta Hort. 810: 475-482.

Crohn, D.M. 2016. Assessing compost quality for agriculture. ANR 8514, University of California. 13 June 2019. <https://anrcatalog.ucanr. edu/Details.aspx?item $\mathrm{No}=8514>$.

Cummings, G., C. Bickford, and L. Nelson. 1971. Fertilizer and lime rates influence highbush blueberry growth and foliar elemental content during establishment. J. Amer. Soc. Hort. Sci. 96:184-186.

Dahnke, W.C. 1990. Testing soils for available nitrogen, p. 120-140. In: R.L. Westerman (ed.). Soil testing and plant analysis. Soil Sci. Soc. Amer. Book Series 3. SSSA, Madison, WI.

DeVetter, L.W., D. Granatstein, E. Kirby, and M. Brady. 2015. Opportunities and challenges of organic highbush blueberry production in Washington State. HortTechnology 25:796804.

Eck, P. 1977. Nitrogen requirements of the highbush blueberry, Vaccinium corymbosum L. J. Amer. Soc. Hort. Sci. 102:816-818.

Eck, P. 1983. Optimum potassium nutritional level for production of highbush blueberry. J. Amer. Soc. Hort. Sci. 108:520-522.

Eck, P. 1988. Blueberry science. Rutgers Univ. Press, New Brunswick, NJ.

Fageria, V.D. 2001. Nutrient interactions in crop plants. J. Plant Nutr. 24:1269-1290.

Fernandez-Salvador, J.A., B.C. Strik, and G.O. Stephenson. 2017. The organic blueberry industry in Oregon: Results of in-person, on-site interviews with growers in 2015. Acta Hort. 1180:409-414.

Forge, T., W. Temple, and A. Bomke. 2013. Using compost as a mulch for highbush blueberry. Acta Hort. 1001:369-374

Gale, E.S., D.M. Sullivan, D. Hemphill, C.G. Cogger, A.I. Bary, and E.A. Myhre. 2006. Estimating plant-available nitrogen release from manures, composts, and specialty products. J. Environ. Qual. 35:2321-2332.

Gough, R.E. 1994. The highbush blueberry and its management. Food Products Press, New York.

Goulart, B.L., K. Demchak, and W.Q. Yang. 1997. Effect of cultural practices on field grown 'Bluecrop' highbush blueberries, with emphasis on mycorrhizal infection levels. Acta Hort. 446:271-278.

Granatstein, D. and K. Mullinix. 2008. Mulching options for northwest organic and conventional orchards. HortScience 43:45-50.

Griggs, W.H. and H.A. Rollins. 1947. The effect of planting treatment and soil management systems on the production of cultivated blueberries. Proc. Amer. Soc. Hort. Sci. 49:213-218.

Hanson, E.J. 2006. Nitrogen nutrition of highbush blueberry. Acta Hort. 715:347-351.

Hancock, J.F. and J. Nelson. 1988. Leaf potassium content and yield in the highbush blueberry. HortScience 23:857-858.

Hart, J., B. Strik, L. White, and W. Yang. 2006. Nutrient management for blueberries in Oregon. Oregon State University Extension Service. EM 8918. 15 Feb. 2019. <http://ir.library. oregonstate.edu/xmlui/bitstream/handle/1957/ 20444/em8918.pdf>.

Horneck, D.A., D.M. Sullivan, J.S. Owen, and J.M. Hart. 2011. Soil test interpretation guide. Oregon State University Extension Service. EC 1478. 30 Apr. 2019. <https://catalog. extension.oregonstate.edu/sites/catalog/files/ project/pdf/ec1478.pdf>.

Julian, J., B. Strik, E. Pond, and W. Yang. 2011. Blueberry economics: The costs of establishing and producing organic blueberries in the Willamette Valley, Oregon. Oregon State Univ. Pub. AEB 0023. 10 Apr. 2019. <http://arec. oregonstate.edu/oaeb/files/pdf/AEB0023.pdf>.

Julian, J.W., B.C. Strik, H.O. Larco, D.R. Bryla, and D.M. Sullivan. 2012. Costs of establishing organic northern highbush blueberry: Impacts of planting method, fertilization, and mulch type. HortScience 47:1-8.

Karp, K., M. Noormets, M. Starast, and T. Paal. 2006. The influence of mulching on nutrition and yield of 'Northblue' blueberry. Acta Hort. 715:301-305.

Kopittke, P.M. and N.W. Menzies. 2007. A review of the use of the basic cation saturation ratio and the "ideal" soil. Soil Sci. Soc. Amer. J. 71:259-265.

Korcak, R.F. 1988. Nutrition of blueberry and other calcifuges. Hort. Rev. 10:183-227.

Kozinski, B. 2006. Influence of mulching and nitrogen fertilization rate on growth and yield of highbush blueberry. Acta Hort. 715:231235.

Krewer, G. and J. Ruter. 2012. Fertilizing bushes three years and older, p. 5. In: Fertilizing highbush blueberries in pine bark beds. Univ. Ga. Coop. Ext. Bull. 1291.

Krewer, G., M. Tertuliano, P. Andersen, O. Liburd, G. Fonsah, H. Serri, and B. Mullinix. 2009. Effect of mulches on the establishment of organically grown blueberries in Georgia. Acta Hort. 810:483-488.

Larco, H.O. 2010. Effect of planting method, weed management, and fertilizer on plant growth and yield of newly established organic highbush blueberries. MS thesis, Oregon State Univ., Corvallis 12 Apr. $2019<$ http://ir.library. oregonstate.edu/xmlui/handle/1957/18065>.

Larco, H., B.C. Strik, D.R. Bryla, and D.M. Sullivan. 2013a. Weed and fertilizer management practices for organic production of highbush blueberries-I. Early plant growth and biomass allocation. HortScience 48:1250 1261.

Larco, H., B.C. Strik, D.R. Bryla, and D.M. Sullivan. 2013b. Weed and fertilizer management practices for organic production of highbush blueberries-II. Impact on plant and soil nutrients, yield, and fruit quality during establishment. HortScience 48:1484-1495.

Larco, H., D.M. Sullivan, B. Strik, and D. Bryla. 2014. Mulch effects on highbush blueberry under organic management. Acta Hort. 1018: 375-382.

Magee, J.B. and J.M. Spiers. 1995. Influence of mulching systems on yield and quality of southern highbush blueberries. In: R.E. Gough and R.F. Korcak (ed.). Blueberries: A century of research. Haworth Press, Inc., Binghamton, NY.

McLean, E.O. 1982. Soil pH and lime requirement, p. 199-223. In: A.L. Page et al. (ed.). Methods of soil analysis, part 2. Agronomy monograph 9, 2nd edition. ASA and SSSA, Madison, WI.

Mehlich, A. 1984. Mehlich-3 soil test extractant: A modification of Mehlich-2 extractant. Commun. Soil Sci. Plant Anal. 15:1409-1416.

Neilsen, G.H., E.J. Houge, T. Forge, and D. Neilsen. 2003a. Mulches and biosolids affect vigor, yield, and leaf nutrition of fertigated high density apple. HortScience 38:41-45.

Neilsen, G.H., E.J. Houge, T. Forge, and D. Neilsen. 2003b. Surface application of mulches and biosolids affect orchard soil properties after 7 years. Can. J. Soil Sci. 83:131-137.

Neilsen, G.H., E.J. Houge, T. Forge, D. Neilsen, and S. Kuchta. 2007. Nutritional implications of biosolids and paper mulch applications in high density apple orchards. Can. J. Plant Sci. 87:551-558.

Nelson, D.W. and L.E. Sommers. 1996. Total carbon, organic carbon and organic matter, p. 961-1010. In: J.M. Bartels et al. (eds.). Methods of soil analysis: Part 3 chemical methods. (3rd ed.) ASA and SSSA Book Series 5, Madison, WI.

Retamales, J.B. and J.F. Hancock. 2012. Blueberries. CABI, Oxfordshire, U.K.

Retamales, J.B. and E.J. Hanson. 1989. Fate of ${ }^{15} \mathrm{~N}-$ labeled urea applied to mature highbush blueberries. J. Amer. Soc. Hort. Sci. 114:920-923.

Runham, S.R., S.J. Town, and J.C. Fitzpatrick. 2000. Evaluation over four seasons of a paper mulch used for weed control in vegetables. Acta Hort. 513:193-201.

Saure, M.C. 2005. Calcium translocation to fleshy fruit: Its mechanism and endogenous control. Scientia Hort. 105:65-89.

Savage, E.F. 1942. Growth responses of blueberries under clean cultivation and various kinds of mulch materials. Proc. Amer. Soc. Hort. Sci. 40:335-337.

Sciarappa, W., S. Polavarapu, J. Barry, P. Oudemans, M. Ehlenfeldt, G. Pavlis, D. Polk, and R. Holdcraft. 2008. Developing an organic production system for Highbush Blueberry. HortScience 43:51-57.

Sikora, L.J. and R.A.K. Szmidt. 2001. Nitrogen sources, mineralization rates, and nitrogen nutrition benefits to plants from composts, $\mathrm{p}$. 287-305. In: P.J. Stofella and B.A. Kahn (eds.). Compost utilization in horticultural cropping systems. CRC Press, Boca Raton, FL.

Spiers, J.M. 1983. Influence of $\mathrm{N}, \mathrm{K}$, and $\mathrm{Na}$ concentration on growth and leaf element content of 'Tifblue' rabbiteye blueberry. HortScience 18:223-224.

Strik, B.C. 2016. A review of optimal systems for organic production of blueberry and blackberry for fresh and processed markets in the northwestern United States. Scientia Hort. 208:92-103.

Strik, B.C. 2014. Organic blueberry production systems - advances in research and industry. Acta Hort. 1017:257-267.

Strik, B., T. Righetti, and H. Rempel. 2006. Black plastic mulch improved the uptake of ${ }^{15} \mathrm{~N}$ from inorganic fertilizer and organic prunings in summer-bearing red raspberry. HortScience 4:272-274

Strik, B.C. and A. Vance. 2015. Seasonal variation in leaf nutrient concentration of northern highbush blueberry cultivars grown in conventional and organic production systems. HortScience 50:1453-1466.

Strik, B.C. and A. Vance. 2017. Weed management strategies in long-term organic blueberry production systems - Impact of mulch type and weed control methods on economics. Acta Hort. 1180:347-352.

Strik, B.C., A.J. Vance, D.R. Bryla, and D.M. Sullivan. 2017a. Organic production systems in northern highbush blueberry: I. Impact of planting method, cultivar, fertilizer, and mulch on yield and fruit quality from planting through maturity. HortScience 52:1201-1213.

Strik, B.C., A.J. Vance, and C.E. Finn. 2017 b. Northern highbush blueberry cultivars differed in yield and fruit quality in two organic production systems from planting to maturity. HortScience 52:844-851.

Sullivan, D.M., N.D. Andrews, C.S. Sullivan, and L.J. Brewer. 2019. OSU organic fertilizer \& cover crop calculator: Predicting plantavailable nitrogen. EM9235. Oregon State University Extension. 2 July 2019. <https:// catalog.extension.oregonstate.edu/em9235>. 
Sullivan, D.M., A.I. Bary, R.O. Miller, and L.J. Brewer. 2018. Interpreting compost analyses. Oregon State University Extension Service. EM 9217. 12 June 2019. <https://catalog. extension.oregonstate.edu/em9217>.

Sullivan, D.M., D.R. Bryla, and R.C. Costello. 2014. Chemical characteristics of custom compost for highbush blueberry, p. 293-311. In: Z. He and H. Zhang (eds.). Applied manure and nutrient chemistry for sustainable agriculture and environment. SpringerVerlag, New York.

Sullivan, D.M., B.C. Strik, and D. Bryla. 2015. Evaluation of alternative mulches for blueberry over five production seasons. Acta Hort. 1076: 171-178.

Townsend, L.R. 1973. Effects of N, P, K, and Mg on the growth and productivity of the highbush blueberry. Can. J. Plant Sci. 53:161-168.

Throop, P.A. and E.J. Hanson. 1997. Effect of application date on absorption of ${ }^{15}$ nitrogen by highbush blueberry. J. Amer. Soc. Hort. Sci. 122:422-426.
U.S. Department of Interior. 2014. Bureau of Reclamation, Boise, ID. AgriMet Weather Station web site. 15 Apr. 2019. <www.usbr.gov/pn/ agrimet/agrimetmap/araoda.html $>$.

USDA-AMS-NOP. 2011. Program handbook: Guidance and instructions for accredited certifying agents \& certified operations. Winter edition, 2011.

Valenzuela-Estrada, L.R., D.R. Bryla, D.M. Sullivan, B.C. Strik. and B.C., 2011. Organic blueberry research project: Roots. eOrganic. Kansas City, MO. 9 Apr. 2019. <http://www.extension.org/ pages/32763/organic-blueberry-productionresearch-project:-roots>.

Van-Buren, J.P. 1979. The chemistry of texture in fruits and vegetables. J. Texture Stud. 10:1-23.

Vance, A.J., P. Jones, and B.C. Strik. 2017. Foliar calcium applications do not improve quality or shelf-life of strawberry, raspberry, blackberry, or blueberry fruit. HortScience 52:382387.

White, L.D. 2006. The effect of pre-plant incorporation with sawdust, sawdust mulch, and nitro- gen fertilizer rate on soil properties and nitrogen uptake and growth of 'Elliott' highbush blueberry. MS Thesis, Oregon State Univ., Corvallis. 15 Mar. 2019. <http://ir. library.oregonstate.edu/xmlui/bitstream/handle/ 1957/1363/WholeThesis.pdf? sequence $=1>$.

Williamson, J., G. Krewer, G. Pavlis, and C.M. Mainland. 2006. Blueberry soil management, nutrition and irrigation. In: N.F. Childers and P.M. Lyrene (ed.). Blueberries for growers, gardeners and promoters. E.O., Gainesville, FL.

Yang, F.-H. 2018. Predictions and practices for reducing heat damage in northern highbush blueberry (Vaccinium corymbosum L.). Ore. State. Univ., Corvallis, PhD Diss. 9 Apr. 2019. $<$ https://ir.library.oregonstate.edu/concern/ graduate_thesis_or_dissertations/hx11xm620>.

Yin, X., C.F. Seavert, J. Turner, R. Núñez-Elisea, and H. Cahn. 2007. Effects of polypropylene groundcover on soil nutrient availability, sweet cherry nutrition, and cash costs and returns. HortScience 42:147-151. 